\title{
Laguncularia Racemosa Leaves from a Mangrove of the Southeast Atlantic Coast, Brazil: Epicuticular Wax, Morphoanatomical Traits and Minerals
}

Cristiane Pimentel Victório ( $\square$ cris.pvictor@gmail.com )

UEZO https://orcid.org/0000-0002-2815-3725

Mayara Silva dos Santos

UEZO: Centro Universitario Estadual da Zona Oeste

Aimêe Cordeiro Dias

UEZO: Centro Universitario Estadual da Zona Oeste

João Pedro Silvério Pena Bento

UFMS: Universidade Federal de Mato Grosso do Sul

Marcelo da Costa Souza

UFRRJ: Universidade Federal Rural do Rio de Janeiro

Naomi Kato Simas

UFRJ: Universidade Federal do Rio de Janeiro

Rosani do Carmo de Oliveira Arruda

UFMS: Universidade Federal de Mato Grosso do Sul

\section{Research Article}

Keywords: Sepetiba Bay, epicuticular wax, leaf cuticle, mangroves, heavy metals, micromorphology

Posted Date: July 23rd, 2021

DOl: https://doi.org/10.21203/rs.3.rs-540578/v1

License: (9) This work is licensed under a Creative Commons Attribution 4.0 International License. Read Full License 


\section{Abstract}

Leaves of Laguncularia racemosa (L.) Gaertn. f. were collected from the following mangroves along Brazil's southeastern Atlantic coast: Coroa Grande (CG), Pedra de Guaratiba (PG) and Marambaia (M). This work aimed to evaluate the presence of minerals by Energy Dispersive X-Ray Spectroscopy (EDS) and Inductively coupled plasma - optical emission spectrometry (ICP-OES); the chemical composition of epicuticular waxes by gas chromatography-mass spectrometry (GC-MS) and the leaf morphoanatomical features. Results revealed variation in metal contents among mangroves in the following ranges: $\mathrm{Al}$ (0.307-0.73), $\mathrm{Cd}(0.004-0.016)$ and $\mathrm{Pb}(0.095-0.325) \mathrm{mg} / \mathrm{mL}$ by ICP-OES. Leaf epicuticular wax contained more than $50 \%$ of triterpenes, in particular the pentacyclic triterpenes lupeol (41.61-55.63\%) and $\beta$-amyrin (8.81-16.35\%), as well as n-alkanes, such as hentriacontane and tetratetracontane. In particular, we observed differences in the micromorphology of the epicuticular wax in the leaves of plants from each of the three evaluated sites, especially around stomatal entrances. Histochemical reaction indicated the presence of zinc in fiber cell walls and druse crystals of leaves.

\section{Introduction}

Mangroves are affected by domestic and industrial pollutants. For example, domestic waste increases phosphates and plasticizers in the environment, while industrial waste varies by industry. These residues are dumped in rivers and flow into the mangroves, tending to accumulate as a result of the large amount of organic matter in sediments and/or filtered particulate matter with the help of tree roots (Souza et al. 2018). Such residues may also enter and accumulate into living organisms or come into contact with microbes inhabiting the soil and, as a consequence, affect different trophic levels (Fernandes 2012).

Leaves correspond to most of the primary production in the mangrove ecosystem and are the main constituents of the litter (Clough et al. 2000), comprising, in turn, the food resource of insects and arboreal crabs. Leaf evaluation allows researchers to detect pollutants in different ecosystems by various morphoanatomical changes or changes in plant metabolism (Bargagli et al. 1998; Flores et al. 2018; Victório et al. 2020). Different studies of mangroves have shown the presence of heavy metals and plasticizers in leaves (Alzahrani et al. 2018; Almahasheer et al. 2018; Victório et al. 2020; Victório et al. 2021; Flores et al. 2021). These substances are taken up by plants through their leaves, but roots are the first and most common organs in contact with pollutants (Cheng et al., 2017). In the roots, pollutants are freely diffused via apoplast or symplast or carried across cells to xylem from which contaminants are transported throughout the plant (Kvesitadze et al. 2015).

Sepetiba Bay is an aquatic saline environment surrounded by a large restinga and a mangrove, ecosystems that have been severely impacted by anthropic activities since the 1970s. This Bay has experienced an increase in industrialization with the construction of the Sepetiba Industrial Complex, the Itaguaí Harbour area and the Industrial District of Santa Cruz. These areas were and are the sites of several metallurgical, petrochemical, and pyrometallurgical smelters, as well as chemical, textile, beverage, and paper plants (SEMA 1998; Wasserman et al. 2013; Victório et al. 2020; Silva and Victório 
2021). The entire region is dubbed the "sacrifice zone" by the extraordinary damage caused to such coastal systems as mangroves, not to mention societal issues arising from the ever-expanding industrial complex and port that receives industrial waste (Viégas 2006). Metal smelting, including Zn, Cd, Al, Fe, and alloy steel are the major economic activities located in Sepetiba Bay's basin, followed by the chemical and paper industries (Lacerda et al. 2004; Wasserman et al. 2001, 2013; Tonhá et al. 2020). Previous studies reported improper disposal of solid wastes, such as $\mathrm{Zn}$ and $\mathrm{Cd}$, which come from an industrial site on Madeira Island, one of the main sources of heavy metal to Sepetiba Bay (Fonseca et al. 2012). Most heavy metal inputs to the bay arrive from rivers, mainly as drainage from the most industrialized and urbanized areas of Sepetiba Bay (Guandu River, Guarda River and Sao Francisco Channel) (Marins et al. 1999; Fonseca et al. 2012). Cyclical periods and the action of marine tidal currents create a dynamism that alters the chemical and physical condition of mangroves; and bring pollutants directly to mangroves (Silvan and Madureira 2012). Heavy metals also reach Sepetiba Bay through the atmosphere. Atmospheric deposition of pollutants emitted outside the Bay area may further contribute to the total heavy metal load (Marins et al. 1999). Heavy metals are not degraded; instead, they become concentrated in water, sediments and plants themselves posing a threat to the entire food chain (Almahasheer et al. 2018).

Laguncularia racemosa (L.) Gaertn. f. (Combretaceae) is an arboreal plant which occurs in mangrove swamps on the Atlantic coasts of the Americas and West Africa (Sugiyama 1995, Nyananyo et at. 2009). A typical pioneer found in the interior of the mangroves and in the transition to the restinga forest, $L$. racemosa is popularly known as mangue-branco. The leaves are slightly succulent with red or purplish petiole. L. racemosa exhibits a complex root system with five types of roots: anchoring, cable, pneumatophores that form pneumathodes at the tip with hypertrophied lenticels, feeding, and lateral aerial roots arising from the pneumatophores (Angeles et al. 2002) that contain lenticels favoring oxygenation in a flooded environment (Tomlinson 1986). This plant does not have barriers in roots to protect against the entry of salt that comes from seawater; instead, it is excreted through specialized glands in the leaves, which, in addition, produce solutes in their tissues that contribute to the maintenance of osmotic balance (Kathiresan and Bingham 2001). It is well known that mangrove plants can absorb, accumulate, degrade/transform and volatilize metals by green remediation processes (Fernandes 2012).

In this study, we investigated the presence of minerals and heavy metals in leaves of L. racemosa collected in different mangroves of Rio de Janeiro situated around Sepetiba Bay - Marambaia, Pedra de Guaratiba and Coroa Grande. In addition, we analyzed the leaf epicuticular waxes for chemical composition and micromorphology, including histochemical tests to evidence the presence of zinc in internal tissues.

\section{Materials And Methods}

\subsection{Plant materials and mangrove areas}


Leaves of Laguncularia racemosa (L.) Gaertn. f. used in the present study were collected from five plants during the reproductive stage at mangroves around Sepetiba Bay between June and July 2012: Coroa

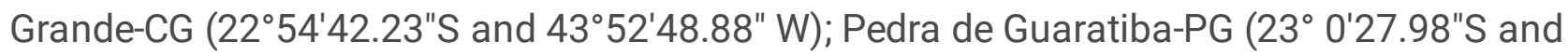

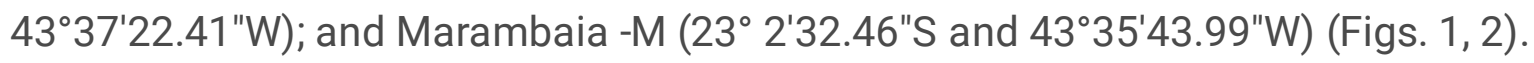

Approximately 30 expanded and mature leaves (Fig. 2) were collected from the third to fifth node, from the apex of the branches, at a height of approximately $1.75 \mathrm{~cm}$ above substrate level, from five individuals for each mangrove site. Vouchers are deposited at the Herbarium RBR at UFRRJ, Rio de Janeiro, Brazil.

\subsection{Analysis of Sepetiba Bay: physicochemistry and heavy metals}

Sepetiba Bay has brackish water according to resolution n. 357/2005 of CONAMA, Brazil (Conselho Nacional do Meio Ambiente) and considering OD, salinity and pH (see Table 1).

Table 1. Total concentration of heavy metals in sediments from Sepetiba Bay, as analyzed by ICP-OES and physicochemical measurements of water at different sampling stations in mangroves around Sepetiba Bay. 


\begin{tabular}{|lll|}
\hline Heavy metals & \multicolumn{2}{l|}{$\begin{array}{l}\text { Mangrove sediments* } \\
(\mathbf{m g} / \mathbf{k g})\end{array}$} \\
\hline Cadmium (Cd) & $3.112^{\mathrm{a}}$ & $0.3-23^{\mathrm{b}}$ \\
\hline Copper (Cu) & $7.706^{\mathrm{a}}$ & $4-1.160^{\mathrm{b}}$ \\
\hline Lead (Pb) & $23.918^{\mathrm{a}}$ & $3-78^{\mathrm{b}}$ \\
\hline Nickel (Ni) & $19.641^{\mathrm{a}}$ & $1-51^{\mathrm{b}}$ \\
\hline Aluminum (Al) & - & $52.64-85.55^{\mathrm{c}}$ \\
\hline Iron (Fe) & - & $35.25-48.27^{\mathrm{C}}$ \\
\hline Manganese (Mn) & - & $227-872^{\mathrm{d}}$ \\
\hline Zinc (Zn) & $317.862^{\mathrm{a}}$ & $17-3.440^{\mathrm{b}}$ \\
\hline Selenium (Se) & - & - \\
\hline Physical parameters & & \\
\hline pH & & \\
\hline Salinity (\%) & \multicolumn{2}{|l}{$6.5-8.1$} \\
\hline Conductivity (mS/cm) & $20-33$ \\
\hline OD (mL/L) & $7.7 .7-21.9$ \\
\hline Turbidity (UNT) & $9.1-11.7$ \\
\hline
\end{tabular}

*Sediment of Sepetiba Bay. (-) not determined. Letters indicate references: ${ }^{a}$ Waserman 2005, ${ }^{b}$ Rocha et al. 2010, 'Herms and Lanzillotta 2012, dGomes et al. 2009, and e (Ferreira et al. 2010; Silva 2017 and Monte 2014).

\subsection{Leaf traits}

For each species and sampling location, ten fully expanded and undamaged leaves were removed from the collected branches. The leaves were photographed individually on a known area for determination of leaf area using ImageJ, v. 1.42q (Rasband 2010) (Fig. 2 D) for subsequent calculation of extract yields. The experiment was conducted in a randomized design with ten replicates for each species and locality. The means of ten replicates and their standard deviations were calculated.

The weight measures were done with a digital analytical balance with four decimal places, applying the parameter in grams. For fresh weight, ten leaves of each individual were used. They were conditioned in paper at room temperature for drying and maintained in an oven at $50^{\circ} \mathrm{C}$. After seven days, the leaves 
were unwrapped and weighed to calculate the dry weight. Later, they were weighed for confirmation of the values. Specific leaf area (SLA) was calculated using the ratio of the leaf area to the corresponding leaf dry weight. These procedures were repeated in the three areas, and the average dry and fresh weight for each species was calculated.

\subsection{Analysis of heavy metals from ashes of leaves by Energy Dispersive X-Ray Spectroscopy (EDS)}

The ashes for metal presence analysis were obtained by burning the leaves in a muffle furnace, as described by the Association of Official Analytical Chemists (AOAC, 1995). Six leaves from each study area were deposited in porcelain crucibles and previously dried at $60^{\circ} \mathrm{C}$ in an air circulation oven for one hour, followed by storage at room temperature. Afterwards, porcelain crucibles that contained leaves were put in an EDG 3P-S muffle furnace for $60 \mathrm{~min}$ at $800^{\circ} \mathrm{C}$.

Ashes from the burning leaves were analyzed by Energy Dispersive X-Ray Spectroscopy (EDS or EDX, Thermo ${ }^{\circledR}$, Noran System Six model, coupled to SEM, Jeol JSM-6380L), following the protocol of Resende (2013) with adaptations. The setup works such that the main electron beam of the Scanning Electron Microscope (SEM) focuses on the sample. Its atoms emit X-rays. Each element of the periodic table has specific and well-defined energy peaks; consequently, it is possible to identify elements present in the sample. The detector will capture the $\mathrm{X}$-ray photons emitted by the sample and measure its energy in electron volts (Ev), counting how many photons are detected with certain energy content. From these results, a spectrum is produced indicating the number of photons for each X-ray-emitted value. An Ev is the amount of energy gained by a single electron when accelerated by a power of one volt in vacuum. Qualitative data were obtained by means of replicates.

\subsection{Analysis of minerals by spectrometry}

Nitric acid digestion of leaves was based on protocols found in the literature (Raposo Junior et al. 2007). In order to determine the minerals, mainly heavy metals (metals with high atomic weight/number/density), leaf samples were dried in an oven at $60^{\circ} \mathrm{C}$ with air circulation, crushed and submitted to digestion with nitric acid 65\% ultrapure (Merck) in a sealed Erlenmeyer. To an Erlenmeyer were transferred 0.2 grams of leaves to which $10 \mathrm{~mL}$ of $\mathrm{HNO}_{3}$ were added under an exhaust hood. Then, the samples were placed in an ultrasound apparatus for 30 minutes. Following this, samples were transferred to an oven to dry at $60^{\circ} \mathrm{C}$ for 60 minutes. After cooling, an additional $5 \mathrm{~mL}$ of $\mathrm{HNO}_{3}$ were added and evaporated off at $95 \pm 5^{\circ} \mathrm{C}$ for 2 more hours. Digested samples were filtered through a quantitative filter $\left(\mathrm{n}^{0} 40\right)$, diluted to $50 \mathrm{ml}$ with distilled-deionized water plus 5 drops of $\mathrm{HNO}_{3}$, and stored in Falcon tubes at low temperature until analysis.

Samples were analyzed by Inductively Coupled Plasma Optical Emission Spectrometry (ICP-OES) 2100 using a PerkinElmer Optima 7300 V ICP/OES apparatus. To prepare the standard curves, a multi-element standard of concentration of $100 \mathrm{mg} / \mathrm{L}$ with the same elements (Spex CertiPrep or Fluka ${ }^{\circledR}$ ) was used. The calibration curves were adjusted according to the analysis of elements. For $\mathrm{Al}, \mathrm{Ba}, \mathrm{Fe}, \mathrm{Zn}, \mathrm{Mg}, \mathrm{Mn}$, and $\mathrm{Sr}$, the curves ranged from 0.01 to $1.0 \mathrm{mg} / \mathrm{L}$; for $\mathrm{Co}, \mathrm{Cr}, \mathrm{Cu}, \mathrm{Ti}, \mathrm{V}, \mathrm{Li}, \mathrm{Mo}$, and $\mathrm{Ni}$, they ranged from 
0.005 to $0.2 \mathrm{mg} / \mathrm{L}$; for $\mathrm{B}, \mathrm{Ca}, \mathrm{Na}$, and $\mathrm{K}$, they ranged from 0.100 to $1.000 \mathrm{mg} / \mathrm{L}$; and for $\mathrm{Se}, \mathrm{As}, \mathrm{Pb}, \mathrm{Be}, \mathrm{Cd}$, and $\mathrm{Sb}$, they ranged from 0.002 to $0.025 \mathrm{mg} / \mathrm{L}$. For $\mathrm{K}, \mathrm{Ca}, \mathrm{Na}$, and $\mathrm{Mg}$, the curves ranged from 1 to 50 $\mathrm{mg} / \mathrm{L}$, for Si from 1 to $50 \mathrm{mg} / \mathrm{L}$, and for $\mathrm{Sn}$, the curves ranged from 0.01 to $0.1 \mathrm{mg} / \mathrm{L}$. Highly efficient ion extraction and transport through the mass spectrometer, as well as detection, afford ICP-OES its ultratrace elemental detection features. Data were obtained by means of three replicates from three to five individuals of each mangrove.

\subsection{Extraction of epicuticular waxes and chemical analysis by gas chromatography (GC) coupled with mass spectrometry (MS)}

After leaf area determination, each leaf was placed in a separate pre-weighed flask containing $50 \mathrm{~mL}$ of chloroform (spectroscopy grade; Tedia ${ }^{\circledR}$ ) and maintained for 30 seconds under gentle manual agitation. This procedure extracts only surface chloroform-soluble compounds without disturbing the leaf interior. Chloroform extracts were maintained at room temperature for solvent evaporation to obtain the solid residue. The amount of wax was expressed per unit leaf area $\left(\mu \mathrm{g} / \mathrm{mm}^{2}\right)$. The experiment was conducted in a randomized design with ten replicates for each individual and locality. The means of three replicates and their standard deviations were calculated. Two $\mathrm{mg}$ of dried extract were dissolved in $200 \mathrm{~mL}$ chloroform. Subsequently, $1 \mu \mathrm{L}$ was injected into a gas chromatograph (GC-2010-Shimadzu) equipped with a flame ionization detector (FID). The analyses were performed on a DB-1MS capillary column (30 m x $0.25 \mathrm{~mm} \times 0.2 \mathrm{~mm}$ ), using He as carrier gas at $1 \mathrm{~mL} / \mathrm{min}$ and a split ratio (50:1). Temperature was increased by $10^{\circ} \mathrm{C} / \mathrm{min}$ from 140 to $300^{\circ} \mathrm{C}$ and then maintained at $300^{\circ} \mathrm{C}$ for $15 \mathrm{~min}$. The injector was maintained at $290^{\circ} \mathrm{C}$ and the detector at $300^{\circ} \mathrm{C}$. Quantification was performed from GC/FID profiles, using relative area (\%). Identification of n-alkanes was based on injection of commercial standards (Sigma Fluka ${ }^{\circledR}$ Alkane standard solution C21-C40). Analysis of a subsample was performed in a GC/MS QP 2010 Plus Shimadzu mass detector, using the same operating conditions as above (except the column; ZB-5MS column $30 \mathrm{~m} \times 0.25 \mathrm{~mm} \times 0.2 \mathrm{~mm}$ ), and the MS scanned for $50-650$ amu at 2 $\mathrm{sec} /$ decade with an electron impact ionization potential of $70 \mathrm{eV}$. Triterpenoid compounds were identified by comparison of the corresponding mass spectra with library data (Spectrum Libraries: NIST05.LIB) complemented with proton nuclear magnetic resonance (1H NMR) spectrometry (Bruker DRX $400 \mathrm{MHz}$ ), using deuterated chloroform as solvent.

\subsection{Microscopy analyses}

For light microscopic observations and measurements, three leaves from each site were fixed in FAA, dehydrated in ethanol series, and stored in ethanol 70\% (Johansen, 1940). Middle portions of leaves were cut in appropriate pieces and embedded in glycolmethacrylate (Historesin $\left.{ }^{\circledR}\right)$, cross sectioned (8 $\mu \mathrm{m}$ thickness) in a rotary microtome (Leica RM 2155), and stained with Toluidine Blue 1\% (O'Brien et al. 1965). Photomicrographs of leaf sections were made using light microscopy (Leica) fitted with a digital camera. The measurements were taken from images obtained from leaf cross sections using a Nikon Eclipse $\mathrm{CI}$ microscope equipped with a digital camera (Moticam Pro 252b). To identify the presence of zinc in plant tissues, free-hand cuts were performed on collected leaves, dehydrated at room temperature 
and exposed to Zincon® reagent, following the method of Seregin et al. (2015) and Seregin and Kozhevnikova (2011). For scanning electron microscopy observations (SEM), segments of dry leaves were mounted on stubs and coated with a thin layer of gold (Denton vacuum Desk IV, LLC). The abaxial and adaxial surfaces of leaves were analyzed with a JEOL-JSM 6390 LV scanning electron microscopy (JEOL, Tokyo, Japan). To analyze the epidermis in frontal view and count the secretory glands $/ \mathrm{mm}^{2}$, leaf epidermises were obtained after treatment with a dissociation solution of hydrogen peroxide and glacial acetic acid (1: 1) and heating in an oven at $60^{\circ} \mathrm{C}$ for $24 \mathrm{~h}$ (Franklin 1945). Afterwards, the epidermises were washed in distilled water many times to remove the dissociation solution. Then, they were stained with $0.05 \%$ basic fuchsine aqueous and mounted in $50 \%$ glycerin on semi-permanent slides (Kraus and Arduin 1997).

\subsection{Statistical analyses}

Morphoanatomical data from leaves and mineral content obtained by ICP were subjected to a two-way analysis of variance (ANOVA), multiple comparisons, considering data for each mangrove (CG, PG and $M)$, followed by Tukey`s test. A difference was considered to be statistically significant when $P<0.05$. All statistical analyses were performed with GraphPad Prism software, version 8.0 for Windows.

\section{Results}

\subsection{Morphological leaf traits}

Leaf weight of $L$. racemosa from Marambaia showed high values in comparison with leaves from CG and PG. Meanwhile, the leaves from PG presented low values for weight and area (Fig. 3). Data from leaf area, together with leaf weight, confirm the low average development of L. racemosa in PG compared to CG and M. Significant difference attributable to leaf area was observed when the data from three locations were analyzed, showing that leaves from PG had smaller values. Leaves from M presented lower specific leaf area (SLA) than that from $C G$ and $P G$, suggesting the influence of pollutants on plant development since $C G$ and $P G$ are surrounded by widespread industrialization.

\subsection{Epicuticular wax chemical composition}

The amount of triterpene content in epicuticular wax per leaf follows the descending order of CG> PG. (Table 2). Epicuticular wax composition presented the major pentacyclic triterpene fagarasterol (lupeol)

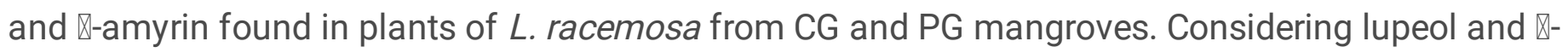
amyrin, the chemical profiles of $\mathrm{L}$. racemosa leaf waxes were consistent. The $n$-alkanes hentriacontane and 8-octadecanone were identified in leaves from CG, while tetratetracontane was only found in leaf samples from PG. This is the first time the epicuticular wax of $L$. racemosa from mangroves of the southeast Atlantic coast has been chemically profiled.

Table 2. Composition of triterpenes identified in epicuticular wax of Laguncularia racemosa collected in Coroa Grande (CG), Pedra de Guaratiba (PG) and Marambaia (M) mangroves, Rio de Janeiro (Brazil), as 
obtained by gas chromatography.

\begin{tabular}{|lllll|}
\hline Constituent & RT (min) & \multicolumn{4}{c|}{ Relative area (\%)* } \\
\cline { 3 - 6 } & & CG & PG & M \\
\hline Hentriacontane & 61.50 & 28.01 & nd & nd \\
\hline Tetratetracontane & 66.17 & nd & 10.93 & nd \\
\hline 8-octadecanone & 70.16 & 6.31 & nd & nd \\
\hline$\beta$-amyrin & 74.63 & 8.81 & 16.35 & nd \\
\hline Fagarasterol (lupeol) & 75.57 & 53.63 & 41.61 & nd \\
\hline Total triterpenes & & 62.44 & 57.96 & nd \\
\hline
\end{tabular}

*Mean amount of wax extracted with chloroform. RT - Retention time obtained by GC. nd- not detected.

\subsection{Mineral content analyzed by EDS}

The analysis of leaf ash made it possible to quantify the ATOM (\%), which is the percentage in number of atoms of the elements present in the sample. Using EDS, the major essential mineral levels found in leaves of $L$. racemosa collected in $\mathrm{M}, \mathrm{CG}$ and $\mathrm{PG}$ were $\mathrm{Na}>\mathrm{Cl}>\mathrm{K}>\mathrm{Ca}>\mathrm{K}$. These minerals are common in saline ecosystems that have input of seawater (Fig. 4a).

The presence of heavy metals was found mainly in leaves of $L$. racemosa from CG and PG. For leaf samples from M, only Al, Si and Fe were detected. Zn was detected only in leaves from CG, the site nearest the industrial center (CG) (Fig. 4b). Cd was not detected.

\subsection{Mineral content analyzed by ICP- OES}

As shown in Table 3, it was possible to observe higher levels of calcium, magnesium and potassium, both in $C G$ and $P G$, when compared to the levels of the same minerals in $M$.

Among the heavy metals in leaf samples, $\mathrm{Cd}$ and $\mathrm{Zn}$ were identified. The levels of the heavy metals $\mathrm{As}, \mathrm{Al}$, $\mathrm{Cr}, \mathrm{Cu}, \mathrm{Pb}$ and Se were similar for $L$. racemosa samples from all three mangroves evaluated. PG and CG samples showed equal results in terms of the order that they bioaccumulated in the leaves: $\mathrm{Fe}>\mathrm{Al}>\mathrm{Zn}>\mathrm{Mn}>\mathrm{Pb}>\mathrm{Cu}>\mathrm{Cd}$ (Table 3$)$, with $\mathrm{Cd}$ varying by having a higher level in $\mathrm{PG}(0.016 \mathrm{mg} / \mathrm{L})$ compared to $C G(0.0012 \mathrm{mg} / \mathrm{L})$. The order of accumulation of metals in leaves of $L$. racemosa from Marambaia was similar to that found in the other mangroves; however, $\mathrm{Al}(0.37 \mathrm{mg} / \mathrm{L})$ was detected at a higher concentration than $\mathrm{Fe}(0.35 \mathrm{mg} / \mathrm{L})$. For comparison, the total concentration of heavy metals within a normal range for plants is presented in Table 3. Specifically, the normal range in plants is 0.03 to 0.9 $\mathrm{mg} / \mathrm{kg}$ for Cd and $50.8 \mathrm{mg} / \mathrm{kg}$ for Zn (Table 3). When compared to chemical fingerprinting of reference plants, $L$. racemosa leaves contain a lower concentration of heavy metals (Table 3 ). For analysis of minerals by ICP, collections were made at two points in CG. Differences between the two CG points 
$\left(\mathrm{CG}^{1}\right.$ and $\mathrm{CG}^{2}$ ) were observed; specifically, $\mathrm{Al}$ and $\mathrm{Na}$ presented higher content in $\mathrm{CG}^{2}$, while $\mathrm{Sr}$ and $\mathrm{Ca}$ presented lower content in $\mathrm{CG}^{2}$ when compared to $\mathrm{CG}^{1}$ (Table 3).

Table 3. Content of minerals, heavy metals and other chemical elements in leaves $(\mathrm{mg} / \mathrm{kg})$ of Laguncularia racemosa by ICP-OES compared to reference plants. Micro- and macronutrients are separated based on physiological use by plants. Leaves were collected in mangroves around Sepetiba Bay, Rio de Janeiro (Brazil): Coroa Grande (CG), Pedra de Guaratiba (PG) and Marambaia (M). 


\begin{tabular}{|c|c|c|c|c|c|}
\hline $\begin{array}{l}\text { Mineral } \\
(\mathrm{mg} / \mathrm{kg})\end{array}$ & $\mathrm{CG}^{1}$ & $\mathrm{CG}^{2}$ & PG & $M$ & $\begin{array}{l}\text { Reference } \\
\text { plants }^{\dagger}\end{array}$ \\
\hline \multicolumn{6}{|l|}{ Metals } \\
\hline Al & $0.31 \pm 0.31$ & $0.74 \pm 0.45$ & $0.38 \pm 0.1$ & $0.37 \pm 0.061$ & 80 \\
\hline As & $0.002 \pm 0$ & $0.002 \pm 0$ & $0.002 \pm 0$ & $0.002 \pm 0$ & \\
\hline $\mathrm{Ba}$ & $0.025 \pm 0.007$ & $0.027 \pm 0.004$ & $0.039 \pm 0.0005$ & $0.025 \pm 0.004$ & 40 \\
\hline $\mathrm{Be}$ & $0.002 \pm 0$ & $0.002 \pm 0$ & $0.002 \pm 0$ & $0.002 \pm 0$ & \\
\hline $\mathrm{Cd}$ & $0.004 \pm 0.003$ & $0.032 \pm 0.01$ & $0.016 \pm 0.01$ & $0.009 \pm 0.02$ & $0.03-0.9$ \\
\hline $\mathrm{Pb}$ & $0.095 \pm 0.16$ & $0.32 \pm 0.13$ & $0.16 \pm 0.12$ & $0.1 \pm 0.17$ & 1.54 \\
\hline $\mathrm{Li}^{\star \star}$ & $0.005 \pm 0$ & $0.005 \pm 0$ & $0.005 \pm 0$ & $0.005 \pm 0$ & \\
\hline $\mathrm{Sr}$ & $0.46 \pm 0.07$ & $0.29 \pm 0.036$ & $0.45 \pm 0.147$ & $0.24 \pm 0.07$ & \\
\hline $\mathrm{Cr}$ & $0.005 \pm 0$ & $0.005 \pm 0$ & $0.005 \pm 0$ & $0.005 \pm 0$ & \\
\hline Sn & $0.01 \pm 0$ & $0.01 \pm 0$ & $0.01 \pm 0$ & $0.01 \pm 0$ & \\
\hline Ti** & $0.008 \pm 0.002$ & $0.006 \pm 0.003$ & $0.005 \pm 0$ & $0.005 \pm 0$ & 5.0 \\
\hline V & $0.005 \pm 0$ & $0.005 \pm 0.0$ & $0.005 \pm 0$ & $0.005 \pm 0$ & \\
\hline \multicolumn{6}{|c|}{ Micronutrients } \\
\hline Co & $0.005 \pm 0$ & $0.005 \pm 0.0$ & $0.005 \pm 0$ & $0.005 \pm 0$ & 0.2 \\
\hline B & $0.126 \pm 0.45$ & $0.1 \pm 0.0$ & $0.21 \pm 0.06$ & $0.35 \pm 0.79$ & \\
\hline$M n^{*}$ & $0.088 \pm 0.0026$ & $0.091 \pm 0.007$ & $0.20 \pm 0.02$ & $0.13 \pm 0.033$ & $15-100$ \\
\hline Mo & $0.01 \pm 0$ & $0.01 \pm 0.0$ & $0.1 \pm 1.69$ & $0.01 \pm 0$ & \\
\hline $\mathrm{Ni}^{\star}$ & $0.007 \pm 0.0081$ & $0.005 \pm 0.0$ & $0.087 \pm 0.141$ & $0.005 \pm 0.004$ & 3.10 \\
\hline$Z n^{*}$ & $0.30 \pm 0.0587$ & $0.26 \pm 0.11$ & $0.33 \pm 0.025$ & $0.25 \pm 0.16$ & 50.80 \\
\hline $\mathrm{Cu}^{*}$ & $0.024 \pm 0.0051$ & $0.028 \pm 0.005$ & $0026 \pm 0.002$ & $0.018 \pm 0.003$ & 10.0 \\
\hline $\mathrm{Fe}^{\star}$ & $0.27 \pm 0.0982$ & $0.33 \pm 0.08$ & $0.51 \pm 0.006$ & $0.36 \pm 0.09$ & 89.22 \\
\hline \multicolumn{6}{|c|}{ Macronutrients } \\
\hline $\mathrm{Na}$ & $31.988 \pm 6.84$ & $68.71 \pm 5.512$ & $38.33 \pm 4.73$ & $92.0 \pm 11.56$ & \\
\hline $\mathrm{Mg}$ & $15.778 \pm 3.03$ & $12.718 \pm 1.13$ & $14.034 \pm 3.83$ & $9.71 \pm 3.006$ & \\
\hline $\mathrm{Ca}$ & $62.94 \pm 11.10$ & $37.25 \pm 3.10$ & $69.23 \pm 19.85$ & $42.18 \pm 8.50$ & \\
\hline $\mathrm{K}$ & $27.09 \pm 5.43$ & $29.126 \pm 1.78$ & $26.025 \pm 2.63$ & $29.063 \pm 7.23$ & \\
\hline
\end{tabular}


Other elements

\begin{tabular}{|c|c|c|c|c|c|}
\hline $\mathrm{Se}$ & $0.005 \pm 0.0$ & $0.007 \pm 0.001$ & $0.006 \pm 0.001$ & $0.006 \pm 0.001$ & \\
\hline $\mathrm{Si}$ & $0.602 \pm 0.16$ & $0.5 \pm 0.07$ & $0.55 \pm 0.04$ & $0.76 \pm 0.24$ & 0.1 \\
\hline $\mathrm{Sb}^{\star \star \star}$ & $0.002 \pm 0.0$ & $0.002 \pm 0.001$ & $0.002 \pm 0.0$ & $0.002 \pm 0.0$ & $(<0.5) 1.5^{\dagger \dagger}$ \\
\hline
\end{tabular}

* Also heavy metals, but considered micronutrients used by plant. ** Light metal. ***Antimony (or stibium) metalloid. ${ }^{\dagger}$ References: Markert 1992, values in $\mathrm{mg} / \mathrm{Kg}$ dry weight. ${ }^{\dagger+}$ Levels in leaves of different plants: Pérez-Sirvent et al. 2011. ${ }^{1,2}$ For analysis of minerals by ICP, collections of leaves were made at two points in CG.

\subsection{Microscopic diagnosis}

The qualitative and quantitative parameters evaluated in $L$. racemosa leaves from the three sites are presented in Fig. 6.

In investigated plants, the epicuticular wax layer covering the leaf surface presented distinct patterns, those being plates, granules, rodlets and crusts, according to the site of collection (Fig. 5). Leaves from Marambaia presented epicuticular wax in crusts and granules covering most of the surface area, but in scales near stomata (Fig. 5a, b). In leaves from Pedra de Guaratiba, the wax layer consisted of crusts and plates throughout the surface, including stomatal cells (Fig. $5 c, d$ ). In leaves from Coroa Grande, the epicuticular wax consisted of granules over common epidermal cells, but a rod pattern near stomata (Fig. $5 e, f)$. Pores of the cavity where salt secretory glands are located were seen in both surfaces (Fig. $5 \mathrm{~g}, \mathrm{~h}$ ).

In cross section, the epicuticular wax and cuticular layer are not easily distinguished under light microscopy, so they were measured together. The thickness of wax+cuticular layer was smaller in $\mathrm{M}$ compared to that for CG for both sides with few differences on the adaxial side between CG and PG (Fig. $6)$.

Laguncularia racemosa has amphistomatic leaves; the ordinary epidermal cells present straight walls (Fig. 6a, b). Unicellular trichomes were detected only in plants collected in CG (Fig. 6a). In cross section, the epidermis consisted of a single layer of epidermal cells (Fig. 6d-f). Common epidermal cells stored phenolic compounds in both surfaces more intensely as detected in plants from CG (Fig. 6e). The adaxial epidermal cells in individuals from M were higher than those of individuals from PG (Fig. 6).

Salt-secreting glands are located in epidermal cavities that invade the mesophyll (Fig. 6 b, c-e). The number of glandular trichomes was constant between the two faces of the leaf and also between the three sites evaluated (2-3 glands $/ \mathrm{mm}^{2}$ ). The secretory structure is supported by short peduncle cells with 3-4 (basal cells) sustaining the secretory cells that form a nearly globose structure (Fig. 6b-c, e). The epidermal cells that surround the opening of the cavity (pore) are palisade-like in cross section, with 
tabular shape, containing phenolics. The salts, mucilage and other substances excreted by this secretory structure first accumulate in the cavity and thereafter are likely released to the external environment through the epidermal pore (Fig. 6e).

The mesophyll is heterogeneous and isolateral in leaves from the three sites investigated and was comprised of two layers of adaxial and abaxial palisade parenchyma with shorter cells when compared with adaxial layers and 4-5 layers of spongy, or water storage, parenchyma (Fig. 6d-f). The thickness of the mesophyll was greater in leaves from PG, but less so in plants from M (Fig. 7). The length of palisade parenchyma cells (adaxial and abaxial) was similar in the leaves evaluated for individuals of the same site; however, when different sites were compared, longer cells were observed in PG and shorter cells in CG. In the first layer of palisade parenchyma under both sides of the epidermis, a strong reaction to phenolic compounds was observed (Fig. 6d-f). The median part of mesophyll is occupied by a spongy parenchyma, similar to water storage parenchyma, with voluminous cells with few, or no, chloroplasts (Fig. 6c). This tissue is thicker in leaves from CG than that from PG. In all samples evaluated, the cell wall of water storage parenchyma presented intense reaction to the mucilage test. The mucilage was observed spread between cells in the mesophyll (Fig. 6f). Idioblasts with druse crystals were observed in the cells of the spongy parenchyma, proportionally more abundant in PG leaves (Fig. 6). Druse crystals presented positive reaction to the Zincon ${ }^{\circledR}$ histochemical test with more intensity in leaves from CG and PG, indicating the presence of this metal (Fig. 6i-j).

The vascular bundles are the collateral type with fibers in the most developed units, forming a cap protecting the phloem (Fig. 6c). Positive reaction to the presence of zinc was observed in vascular fibers in $C G$ and PG leaves (Fig. 6i-j). A parenchymal sheath (endodermis) is present and is better observed in the larger bundles. It does not touch the epidermis. Phenolic compounds and idioblasts with druse crystals are associated with vascular tissue. Regarding the vascular system, we did not observe any difference among leaf samples from different collection sites.

Midvein - The epidermal cells on the adaxial face had a rectangular shape (Fig. $6 \mathrm{~g}$ ), and those on the abaxial face were square to papillose. The height of the epidermal cells and the cuticle layer was higher in PG and lower in M. Under adaxial and abaxial epidermal sides, we observed 6-8 layers and 1-2 layers, respectively, of regular parenchyma storing phenolic compounds and crystals. In the region of the main vein, the parenchyma cells are isodiametric, separated by intercellular spaces filled with mucilage (Fig. $6 \mathrm{~g}$ ). The main vascular bundle is the collateral type, with a reniform shape, surrounded by fibers and collenchyma (Fig. 6h). The width of the main rib is proportional to the length in height of the main vascular bundle, longer in PG and shorter in CG. The width of the main rib was longer in $\mathrm{M}$ and shorter in CG.

\section{Discussion}

Among the studied mangroves of Sepetiba Bay, Marambaia is thought to be the most preserved since it lies east of the Coroa Grande and Santa Cruz industrial complex and, hence, the most distant mangrove 
from anthropic pressure. It is also located in an area under military protection. In 2010 Ferreira et al. found that the concentration of heavy metals in Sepetiba Bay did not exceed the limits recommended in CONAMA Resolution No. 344/2004. However, Cd, Zn and $\mathrm{Cu}$ in the water did show unsatisfactory values in some parts of Sepetiba Bay when assessed according to resolution $N^{0} 357 / 2005$. One of the many factors that alter the concentration of minerals in Sepetiba Bay is the frequent movement of tidewater and sediment from water entering the bay. In addition, industrial activities have production rates that can alternately reduce and increase pollution. Sepetiba Bay is a coastal area sensitive to regional environmental changes that can create an ecotone where interactions between land and water take place. According to Ribeiro et al. (2013), metal mobility may also change in the short term. The average of dry weight showed a decreasing pattern following the order $M>C G>P G$ (Fig. 4).

Severoglu et al. (2015) suggest that heavy metals constitute one of the main abiotic agents related to growth reduction and alteration in physiological processes. The high SLA value of $L$. racemosa collected in $C G$ and $P G$ mangroves is consistent with the pollution data based on proximity to the industrial complex. SLA is an important indicator of the impact of pollution in the environment, and it can may be a parameter involved in protection and adaptation of plants (Wuytack et al. 2011).

The amount of $\mathrm{Na}$ is three times greater in leaves of Marambaia compared to leaves examined from CG and PG mangroves. This result could be attributed to the degree of salinity in the region where a high hydrodynamism is known to significantly change salinity. Soil salinity can interfere with the uptake and exchange of ions in the soil-plant system, which, in turn, is reflected in the morphology and structure of plants (Bartz et al. 2015).

Leaf structure of L. racemosa was analyzed by Francisco et al. (2009) who reported the presence of leaf glands and trichomes, as well as salt secretory glands. They considered these features to be adaptations to the saline ecosystem. Here we added information about the quantity of salt secretory glands in the leaves of $L$. racemosa plants growing in different mangroves around Sepetiba Bay and data about the micromorphology of epicuticular wax. Some microscopic views showed the high salt content on leaves and around salt glands (Fig. 5). Evidence suggests that mature leaves of L. racemosa can secrete salt according to its concentration in the soil. That is, if salt increases in the substrate, then salt secretion will be higher in leaves (Sobrado 2004). Through salt glands, salt-tolerant plants also can expel heavy metals (Arrivabene et al. 2016). Leaf structures are particularly relevant to the ecological success of this species, which occupies environments where salinity is high. No leaf samples from mangroves evaluated showed morphological or structural damage.

The plant cuticle consists of nonpolar substances such as cutin, which is the matrix associated with waxes. It is secreted by cells of the epidermis and deposited on an organ of the plant's surface, such as the leaf. It also seals flowers, stems, and fruits, protecting them from biotic and abiotic stresses (Kunst and Samuels 2009). Intracuticular wax is embedded into the cuticle, and epicuticular wax is found on the cuticle's surface (Koch and Ensikat, 2005). Cuticular waxes are involved in guarding against excessive leaf water loss (residual transpiration) (Hasanuzzaman et al. 2017). The presence of $n$-alkanes and 
triterpenes, as the main constituents of epicuticular wax, is recurrent among restinga and mangrove plants that use residual transpiration as a mechanism of tolerance under salinity stress (Oku et al. 2003; Zorat et al. 2011; Hasanuzzaman et al. 2017; Victório et al. 2020). Pentacyclic triterpenoids, such as $\beta$ amyrin and lupeol, which are representative of the oleanane and lupane groups, are widely distributed in mangrove plants associated with features tolerant to salt (Basyuni et al. 2012). Pentacyclic triterpenes were identified as the main components of $A$. shaueriana epicuticular wax (Victório et al. 2020), as well as the main components of $L$. racemosa leaves in this study. However, our results are different from those of Rafii et al. (1996) who verified only trace amounts of triterpenes in leaf wax of L. racemosa from Guyana (western Atlantic coast) and $8.5 \%$ in wax extract in a population from Gabon (eastern Atlantic coast) that did not present lupeol.

The presence of hydrocarbons in leaf epicuticular wax has proven valuable in chemotaxonomic studies of different botanic families. Alkanes were the most abundant compounds among the hydrocarbons, highlighting hentriacontane (28.01-45.36\%) in leaf wax collected in CG. The hydrocarbons hentriacontane and octadecanone are present in leaves of Rhizophora mangle from Africa (Dodd et al. 1995), and hentriacontane is present in leaves of A. shaueriana (Victório et al. 2020). The presence of the hydrocarbon hentriacontane is recorded for the epicuticular waxes of several plant species (Wang et al. 1999), but this was the first evidence of its presence in the Laguncularia genus. As constituents of epicuticular wax, n-alkanes, but not triterpenes, seem to be related to a reduction in cuticular water loss (Buschhaus and Jetter 2012).

In studies with conifer (Pinus sy/vestris L.) seedlings, Burkhardt and Pariyar (2014) verified that air pollution degraded ('erosion') epicuticular waxes that revealed an amorphous appearance resulting in low drought tolerance. These symptoms, which are easily visible through an analysis of the leaf surface by scanning electron microscopy (SEM), are provoked by very diverse chemical environments, such as acid rain or fog, simultaneous exposure to $\mathrm{SO}_{2}$ and $\mathrm{NH}_{3}$ or car exhaust, as pointed out by Viskari et al. (2000). Studies of Arrivabene et al. (2015) detected a higher amount of particulate material, including iron, on the leaf surface of $A$. schaueriana and L. racemosa, the leaves of which contain salt glands in comparison to Rhizophora mangle. The presence of hydrophobic epicuticular wax covering the leaf blades may be associated with the absorption of chemicals of equal polarity, such as phthalates, pesticides and others. Plasticizers were detected in the leaf epicuticular wax of $A$. shaueriana and $R$. mangle from the same mangroves (Victório et al. 2021). Cuticular waxes also act in controlling loss and uptake of polar solutes (Hasanuzzaman et al. 2017).

Cutin is integrated into superimposed waxes; it is an extracellular layer that lines the epidermal cells externally. When plant cells are subjected to stress, the results show up later as alterations in the synthesis of wax, in turn affecting gene expression. Apart from internal processes, biotic and abiotic stresses are involved in the regulation of plant cuticle biosynthesis (Fich et al. 2016; Tafolla-Arellano et al. 2018). Some reports show consistency between the morphology of wax and its composition (Koch and Ensikat 2008). However, variations in wax types caused by changing environmental conditions have been 
suggested during crystallization, and genes associated with cuticle formation have shown responsiveness to environmental conditions (Koch and Ensikat 2008).

It has been reported that uptake of metals from both soil and leaves influences cuticular wax layer and permeability. A positive correlation between transpiration rate and cadmium (Cd) concentration was reported in Beta vulgaris plants, potentially affecting cuticle biosynthesis and composition. Consequently, changes in chemical composition are reflected in permeability which can then result in high water losses through the cuticle (Greger and Johansson 1992). Evidence suggests that heavy metals alter the cuticle, e.g., the expression of genes involved in $\mathrm{Cd}$ tolerance, while Fe deficiency was shown to reduce the amount of cuticular lipids that influence water retention, solute permeability, pathogen infection and disease resistance (Fernández et al. 2008; Tafolla-Arellano et al. 2018).

Mangroves are also exposed to pollution of particulate material through the atmosphere owing to their coastal distribution and proximity to urban centers (Bayen 2012). Particulate pollutants deposited on the leaf surface may be absorbed by leaf tissues and alter the chemical structure of epicuticular waxes, thereby causing morphoanatomical damage, such as chlorosis, necrosis, reduction in photosynthesis and gas exchange (Prasad and Hagemeyer 1999; Naidoo and Chirkoot 2004; Arrivabene et al. 2015). Such absorption may also induce physiological responses of plants and alter production of metabolites. In studies reporting on the epicuticular waxes of Coffea arabica, Lichston and Godoy (2006) verified a decrease in wax content and morphological alteration of wax when leaves were exposed to a copperbased fungicide.

Plants from mangroves, mainly in polluted areas, incorporate some metals in organ tissues. However, results show that metal concentration attained in biota is only high if the plants have accumulated features and are hyperaccumulators (Saenger and McConchie, 2004). Laguncularia racemosa plants accumulate high concentrations of $\mathrm{Cr}$ in roots, but low mobility of this element results in correspondingly low content in leaves (Rocha et al. 2009). Saenger and McConchie (2004) also indicate that young leaves accumulate more metals than mature leaves. The metal contents in leaves of mangroves sampled in this study are lower than those observed in normal reference plants grown in uncontaminated soils. Machado et al. (2002) conducted a study with L. racemosa in Guanabara Bay (RJ) and found that heavy metals tend to accumulate in chemical forms that reduce their mobility and, hence, absorption by biota. In addition, a low translocation of heavy metals was observed from the leaves of the litter to other trophic levels, suggesting the low bioavailability of these heavy metals. Leaves may accumulate heavy metals or metabolize them. When leaves fall in the mangrove substrate, a low amount of metals present in the leaf litter is returned to the soil by decomposition and mineralization processes, becoming bioavailable in the environment in a way that culminates in biomagnification processes along the food chain. However, the release of metals from fallen leaves is low (Saenger and McConchie 2004). This ability to keep heavy metals in unavailable forms, together with resistance to these elements in the sediment, may explain the low levels of some heavy metals found in the aerial part of L. racemosa. Still, leaves are important organs in the analysis of heavy metals, essentially because many processes of primary and secondary metabolism occur in leaves. In addition, because of transpiration, the water rises from the root carrying 
the pollutants dissolved in the water when they are not deposited on the leaf owing to their presence in the atmosphere (Liang et al. 2017).

EDS analysis evidenced high concentrations of calcium (Ca), magnesium $(\mathrm{Mg})$, potassium $(\mathrm{K})$ and sodium ( $\mathrm{Na}$ ) (Fig. 4), indicating the high salinity of the mangrove environment surrounding Sepetiba Bay where the marine influence is greater (Lacerda et al. 1985). The ability to tolerate high concentrations of salt may be associated with tolerance to heavy metals since both depend, in part, on common physiological mechanisms (Manousaki and Kalogerakis 2011). Ca, K, and Mg will work by inhibiting the absorption of heavy metals, and their levels will increase whenever stress is caused by heavy metals. Potassium will act to restore osmotic pressure, and the plant will protect itself by increasing the levels of $\mathrm{Ca}$ and $\mathrm{Mg}$ to a threshold, after which they start to decrease (Severeglu et al. 2015). Using EDS, Zn was detected only in leaves from CG (0.39 ATOM\%). Its absence in other mangroves may be associated with experimental conditions or optimization of the analysis by EDS since the presence of $\mathrm{Zn}$ for all mangroves was verified in analyses by ICP-OES. Comparing these methods, a large number of minerals were identified through ICP, revealing that this type of analysis is more accurate than that performed with EDS. However, the use of standards is required in EDS analysis to better indicate the concentration of minerals.

Considering the analysis by ICP-OES, it follows that CG, as the mangrove area nearest the industrial complex, would have high values of heavy metals, as verified by both spectroscopy and spectrometry. The high concentrations of $\mathrm{Zn}(0.335 \mathrm{mg} / \mathrm{L})$ and $\mathrm{Cd}(0.016 \mathrm{~m} / \mathrm{L})$ for PG samples in relation to other mangroves also suggest the influence of industrial pollutants in this area, in contrast to Marambaia, which would be the most distant from industrial pollution. Through the analysis by ICP-OES, only high concentrations of $\mathrm{Zn}$ were confirmed in CG. $\mathrm{Zn}$ is a metal present in the lithosphere, but it also indicates anthropogenic pollution. $\mathrm{Zn}$ is a naturally occurring metal, but it is often associated with anthropogenic sources, and it can be considered a key indicator of polluted areas, such as contaminated urban areas (Alharbi et al. 2019). Also, $\mathrm{Zn}$ is probably associated with the waste from the metallurgical plants in the West Zone of Rio de Janeiro and Coroa Grande (Itaguai City). The higher concentration of Zn ( $<50 \mathrm{ppm}$ ) was also observed in leaves of $L$. racemosa in experiments carried out by Bernini et al. (2010) from leaves collected in an estuarine mangrove of the São Mateus River, Espírito Santo, Brazil.

According to Ramos and Silva (2006), mangrove forests are important biochemical filters of heavy metals to coastal areas since these elements would otherwise be accumulated in the organs of perennials, such as branches and leaves, with high renewal rate. Heavy metals like $\mathrm{Cd}, \mathrm{Cr}, \mathrm{Pb}$ and $\mathrm{Zn}$ present high toxicity to environment, and their significant bioaccumulation causes many problems in ecosystems because they are not biologically degraded, but rather accumulate in biota and in abiotic environments as trapped particulate in mangrove sediments (Mathivanan and Rajaram 2013).

Mineral resources correspond to an important material base for socioeconomic progress. Besides $\mathrm{Zn}$ and $\mathrm{Cd}$, other metals, such as $\mathrm{Ba}, \mathrm{Si}, \mathrm{Sb}, \mathrm{Ti}$ and $\mathrm{V}$, are employed in different industries, in particular, those in the Sepetiba Bay area, and thus also found in leaves of $L$. racemosa. For example, $\mathrm{Ti}, \mathrm{Sb}$ and $\mathrm{V}$ are used 
in the production of metal alloys. Because of the lower values from some minerals, it is possible that they do not originate from industrial sources, but, instead, are the result of biogeochemical cycling.

Barium $(\mathrm{Ba})$ is a toxic chemical used in various industries, such as oil well drilling, production of rubber and paper, fireworks, manufacture of glass, paints and pigments, composition of batteries, and the composition of fluorescent lamps, and it causes many disturbances in plant development (Sleimi et al. 2021). Silicon (Si) has important applications in computers and the production of silicone polymers. Antimony ( $\mathrm{Sb}$ ) is employed mainly in metal alloys, and some fire-resistant compounds are also used in paintings, ceramics, enamels, rubber vulcanization and fireworks. However, $\mathrm{Sb}$ is potentially toxic and has no role in biological functions. Sb in plants can lead to toxicity, so low to moderate concentrations can result in damage to plant growth and development, including photosynthesis, lipid peroxidation and oxidative stress (Natasha et al. 2019). The maximum value reported in leaves is $1.5 \mathrm{mg} / \mathrm{kg}$, but in most samples, like our data $(0.2 \mathrm{mg} / \mathrm{kg}$ ), the concentrations were below $0.5 \mathrm{mg} / \mathrm{kg}$ (Pérez-Sirvent et al. 2011). These chemical elements are indicators of industrial development and were detected in samples of $\mathrm{L}$. racemosa leaves, but not in concentrations considered toxic.

Vanadium (V) is a metal widely present in the environment and distributed in leaf organs of plants in low concentrations. Compared to other species, the leaves of L. racemosa accumulated it at very low concentration $(0.05 \mathrm{mg} / \mathrm{kg})$. The lowest registered to leaves was found in smilograss - Piptatherum miliaceum ( $0.1 \mathrm{mg} / \mathrm{kg}$ of V) (Aihemaiti et al. 2020). Studies indicated that some phosphate fertilizers present high concentrations of $\mathrm{V}(90-180 \mathrm{mg} / \mathrm{kg})$ as a contaminant (Vachirapatama et al. 2002), suggesting that this element is widespread in soils, water and vegetables through phosphorus fertilization. For plants, depending on concentration, $V$ can be harmful to development in high concentrations by disrupting energy metabolism and matter cycling. It can also inhibit some enzymes, protein synthesis, and ion transport, as well as reduce growth rate, cause root and shoot abnormalities, or even death of plants. In low levels, the results may be positive by elevating plant height, root length, and biomass production associated with increased chlorophyll content, seed germination, essential mineral uptake, and assimilation of nitrogen and its utilization (Aihemaiti et al. 2020).

From an anatomical point of view, the $L$. racemosa leaf presented tissue organization similar to that described for the family and genus mentioned in the classical literature (Metcalfe and Chalk 1950). The anatomical pattern observed in the samples of $L$. racemosa differed slightly from that described by Silva et al. (2010), who evaluated the same species in a mangrove in the state of São Paulo by comparing a highly impacted area with a non-impacted one. In the epidermis, for example, the authors observed only epicuticular wax in granules. Baker (1980) suggests that epicuticular wax in plates are produced by primary alcohols, such as triterpenoids, resulting in amorphous morphology, as we observed here.

Salt-secreting structures in the epidermis seem to be an unusual feature. It has been suggested that plants evolutionarily tend to adapt to the saline condition rather than having salt glands. Only a few orders of Angiosperms such as Poales and Myrtales, including Combretaceae, Caryophyllales, Lamiales, and Solanales have salt glands (Flowers et al. 2010), indicating an independent evolutive origin. The 
secretory glands actively eliminate salts, keeping them within certain limits (Larcher 1995). In our study, the number of salt glands varied (2-3 glands $/ \mathrm{mm}^{2}$ ), different from what was observed by Silva et al. (2010) who found less than $1 \mathrm{gland} / \mathrm{mm}^{2}$. This reduction may be related to the levels of salinity found in each collection site, especially from the proximity of large rivers that flow into the site investigated by Silva et al. (2010) and which would have reduced the salinity of the soil. The very high content of $\mathrm{Na}$ in leaves from $M$, compared to that found in leaf samples from CG and PG mangroves, is simply suggestive of high salinity as a characteristic of the local ecosystem. This study did not verify any changes in the patterns of salt gland distribution for $L$. racemosa. The anatomical characteristics of the salt glands, which are located at the bottom of an epidermal cavity, corroborate the description provided by Francisco et al. (2009) and Dassanayake and Larkin (2017) regarding cell organization and composition.

In the mesophyll of L. racemosa herein evaluated, we observed that the thickness varied from 397.94 to $430.13 \mu \mathrm{m}$, values similar to those found in leaves collected in northern Brazil (Lucena et al. 2011) in a place not affected by industrial pollution, suggesting that the leaves of the species evaluated here did not present significant alterations in the organization of the palisade and spongy parenchyma. In leaves investigated here, we observed an isolateral structure in the three sites selected, even as we acknowledge the dorsiventral mesophyll cited by Lima et al. (2013) and Lucena et al. (2011). Isolateral leaves are found in plants living in sites where incident light is received from upper and lower orientations, possibly improving the photosynthetic process in an otherwise growth-limiting environment. As part of the mesophyll, the spongy parenchyma, similar to an aquiferous tissue, is a common, but no less remarkable, tissue in halophytes and has a fundamental role in the dilution of salts that are absorbed together with water and that can accumulate in levels toxic to the plant (Silva et al. 2020; Larcher 1996).

In the epidermis and mesophyll, we observed an intense reaction pointing to the presence of phenolic compounds in all collection areas. The occurrence of phenolic compounds, including flavonoids and derived phenolic acids, in the epidermal cells and in the palisade parenchyma close to the adaxial and abaxial surfaces may be related to photoprotection of the underlying tissues, guaranteeing their integrity, even under conditions of intense luminosity, as they relieve the photo-oxidative stress and limit the formation of reactive oxygen species (ROS) in chloroplasts or reduce their formation (Zhang et al. 2018).

Histochemical analyses revealed the presence of $\mathrm{Zn}$ associated with druses in the parenchymatic tissue of the leaves. According to Silva et al. (2010), most vascular plants store some type of mineralized material, with druses being the most common form. One of the functions of the deposition of calcium oxalate in the leaves, the main substance of the composition of druses, is to maintain a low concentration of $\mathrm{Ca}$ in the vicinity of the cells of the stoma. Ca is engaged during the opening of the stomata, and the greater number of druses may be related to several changes in metabolism (Silva et al. 2010), including those caused by heavy metal stress, which explains the large number of druses in histological analyses.

\section{Conclusion}


The $L$. racemosa epicuticular wax studied revealed a high concentration of the pentacyclic triterpenes fagarasterol (lupeol) and $\beta$-amirine, as well as n-alkanes, such as hentriacontane (28.01\%), in Coroa Grande mangrove. This study showed variability in wax layer micromorphology among leaves from each mangrove investigated, including the morphological patterns mentioned for plants with the presence of terpenoids in the wax composition. The anatomical features correspond to the physiology of plants growing in saline environments under intense luminosity, as indicated by isolateral structure, not described up to now for $L$. racemosa.

In general, the results showed that accumulation of heavy metals in leaves of $L$. racemosa, as revealed by ICP-OES, did not reach phytotoxic concentrations or toxic levels, according to the reference values. The metal content found in $L$. racemosa leaves is instructive insofar as pollutants associated with anthropic activity in the study area. We herein validated an association with industrial plants engaged in metallurgy, electronics, and other industries that deposit toxic materials into the water and soil. Thus, the values of $\mathrm{Pb}$ and $\mathrm{Cd}$ indicated significant anthropogenic contributions to pollution of Sepetiba Bay.

Through histochemical tests, it was possible to observe the presence of $\mathrm{Zn}$ in such leaf tissues as sclerenchyma associated with vascular system and crystals, suggesting influence of heavy metals on leaf metabolism. However, other variations in physical conditions may change leaf metabolism in the same Bay. These data also point to point to this plant as a bioindicator and/or bioaccumulator in accordance with the proposal of Ramos and Geraldo (2007). Further studies are necessary to analyze the concentration limits of heavy metals in the organs of this species. Nonetheless, it can be speculated that the leaves of such plants can serve as monitors of environmental quality.

\section{Declarations}

Not applicable

\section{Ethics approval and consent to participate}

Not applicable

\section{Consent for publication}

Not applicable

\section{Availability of data and materials}

All data generated or analysed during this study are included in this published article [and its supplementary information files]

\section{Competing interests}

The authors declare that they have no competing interests. 


\section{Funding}

Fundação Carlos Chagas Filho de Amparo à Pesquisa do Estado do Rio de Janeiro (FAPERJ, RJ, Brazil): E-26/111.687/2011 and E-26/110.781/2011.

\section{Authors' contribution}

We declare that all work performed in compiling this article was done by the authors.

C.P.V. designed the study, collected plant material, conducted the leaf extractions and analysis of minerals and epicuticular wax, interpreted the results, and drafted the manuscript.

M.S.S. evaluated morphological parameters, extracted the epicuticular wax for analysis, and prepared leaf samples for mineral analysis.

A.C.D. evaluated morphological parameters and prepared leaf samples for mineral analysis.

J.P.S.P.B. prepared anatomical slides and descriptions and performed leaf tissue measurements and light photomicrography.

M.C.S. collected and identified plant material.

N.K.S. analyzed the composition of epicuticular wax and interpreted the results.

R. C. O. A. conducted the anatomical analysis and description, prepared the histochemical tests, interpreted the results, and drafted the manuscript.

\section{Acknowledgements}

We are grateful to the Brazilian Army for providing access to the Marambaia restinga to collect raw material used in this study. We also acknowledge the technician Luiz Felipe Plaça from UFMS for his support in the SEM-EDS analyses and Companhia de Pesquisa de Recursos Minerais - CPRM, RJ for the ICP-OES analysis.

\section{References}

1. Aihemaiti A, Gao Y, Meng Y, Chen X, Liu J, Xiang H, Xu Y, Jiang J (2019) Review of plant-vanadium physiological interactions, bioaccumulation, and bioremediation of vanadium-contaminated sites. Sci Total Environ 712: 135637. https://doi.org/10.1016/j.scitotenv.2019.135637

2. Alharbi H, Pasha MJ, Al-Shams MAS (2019) Influence of different urban structures on metal contamination in two metropolitan cities. Sci Rep 9:4920. https://doi.org/10.1038/s41598-01940180-x

3. Almahasheer H, Serrano O, Duarte CM, Irigoien X (2018) Remobilization of Heavy Metals by Mangrove Leaves. Front Mar Sci 5:1-10. https://doi.org/10.3389/fmars.2018.00484 
4. Alzahrani DA, Selim E-MM, El-Sherbiny MM (2018) Ecological assessment of heavy metals in the grey mangrove (Avicennia marina) and associated sediments along the red sea coast of Saudi Arabia. Oceanologia 60:513-526. https://doi.org/10.1016/j.oceano.2018.04.002

5. Alcaraz CF, Sánchez MF, Giménez JL (1991) Ascorbato de titânio, fertilizante foliar. Agricultura 708:636-638.

6. Angeles G, López-Portillo J, Ortega-Escalona F (2002) Functional anatomy of the secondary xylem of roots of the mangrove Laguncularia racemosa (L.) Gaertn. (Combretaceae). Trees 16:338-345.

7. Baker, EA (1980) Chemistry and morphology of plant epicuticular waxes in The Plant Cuticle Cutler DF, Alvin KL, Price CE Academic Press, London, pp 139-165.

8. Bargagli R (1998) Plants as Biomonitors In: Bargagli R (ed) Trace elements in terrestrial plants: an ecophysiological approach to biomonitoring and biorecovery, $1^{\text {a }}$ edn. Springer, Berlin Heidelberg, New York, pp 79.

9. Basyuni M, Baba S, Kinjo Y, Putri LAP, Hakim L, Oku H (2012) Salt-dependent increase in triterpenoids is reversible upon transfer to fresh water in mangrove plants Kandelia candel and Bruguiera gymnorrhiza. J Plant Physiol 169:1903-1908. https://doi.org/10.1016/j.jplph.2012.08.005

10. Bartz MC, Melo Júnior JCF, Larcher L (2015) Variação morfológica de Laguncularia racemosa (L.) C. F. Gaertn. (Combretaceae) em áreas de manguezal e de transição entre manguezal e floresta de restinga. Biotemas 28:21-29. https://doi.org/10.5007/2175-7925.2015v28n1p21

11. Bernini E, da Silva MAB, Do Carmo TMS, Cuzzuol GRF (2010) Spatial and temporal variation of the nutrients in the sediment and leaves of two Brazilian mangrove species and their role in the retention of environmental heavy metals. Braz J Plant Physiol 22:177-187. https://doi.org/10.1590/S167704202010000300005

12. Burkhardt J, Pariyar S (2014) Particulate pollutants are capable to 'degrade' epicuticular waxes and to decrease the drought tolerance of Scots pine (Pinus sylvestris L.). Environ Pollut 184:659-667. https://doi.org/10.1016/j.envpol.2013.04.041

13. Buschhaus $C$, Jetter R (2012) Composition and physiological function of the wax layers coating Arabidopsis leaves: $\beta$-amyrin negatively affects the intracuticular water barrier. Plant Physiol 160:1120-1129. https://doi.org/10.1104/pp.112.198473

14. Clough BF, Tan DT, Phuong DX (2000) Canopy leaf area index and litter fall in stands of the mangrove Rhizophora apiculata of different age in the Mekong Delta, Vietnam. Aquat Bot 66:311320. https://doi.org/10.1016/S0304-3770(99)00081-9

15. Dassanayake M, Larkin JC (2017) Making Plants Break a Sweat: The Structure, Function, and Evolution of Plant Salt Glands. Front Plant Sci volume 8:406. https://doi.org/10.3389/fpls.2017.00406

16. Ferreira AP, Horta MAP, Cunha CLN (2010) Avaliação das concentrações de metais pesados no sedimento, na água e nos órgãos de Nycticorax nycticorax (Garça-da-noite) na Baía de Sepetiba, RJ, Brasil. J Integrated Coastal Zone Management 10:229-241. 
17. Fich EA, Segerson NA, Rose JKC (2016) The plant polyester cutin: biosynthesis, structure, and biological roles. Annu Rev Plant Biol 67:207-233. https://doi.org/10.1146/annurev-arplant-043015111929

18. Flores VR; Victório CP, Direito ICN, Cardoso AM (2018) Heavy Metals Accumulation in Banana (Musa spp.) Leaves from Industrial Area in Rio de Janeiro. Orbital: The Electronic Journal of Chemistry 10:364-366. http://dx.doi.org/10.17807/orbital.v10i4.1054

19. Flores VR, Berbert L, Succar JB, Victório CP, Direito IC, Cardoso AM (in press) Avicennia schaueriana as a highly efficient accumulator for manganese in Sepetiba Bay, Brazil. Intern J Environ Sci Technol

20. Fonseca EF, Baptista Neto JA, Silva CG (2012) Heavy metal accumulation in mangrove sediments surrounding a large waste reservoir of a local metallurgical plant, Sepetiba Bay, SE, Brazil. Environ Earth Sci 70:643-650. https://doi.org/10.1007/s12665-012-2148-3

21. Francisco AM, Díaz M, Romano M, Sánchez F (2009) Descripción morfoanatómica de los tipos de glândulas foliares en el mangle blanco Laguncularia racemosa L. Gaertn (f.). Acta Micros 18:237 252.

22. Gomes FC, Godoy JM, Godoy MLDP et al (2009) Metal 112 concentrations, fluxes, inventories and chronologies in sediments from Sepetiba and Ribeira Bays: a comparative study. Mar Pollut Bull 59:123-133. https://doi.org/10.1016/j.marpolbul.2009.03.015

23. Hasanuzzaman M, Davies NW, Shabala L, Zhou M, Brodribb TJ, Shabala S (2017) Residual transpiration as a component of salinity stress tolerance mechanism: a case study for barley. BMC Plant Biol 17:1-12. https://doi.org/10.1186/s12870-017-1054-y

24. Herms FW, Lanzillotta HAA (2012) Influência de atividades industriais na população por metais no Rio Guandu, Baía de Sepetiba - RJ. In: Tubbs Filho D, Antunes JCO, Vettorazzi JS. Bacia Hidrográfica dos rios Guandu, da Guarda e Guandu-Mirim - Experiências para a gestão dos recursos hídricos. INEA (ed.), Rio de Janeiro

25. Kabata-Pendias A, Pendias H (1984) Trace Elements in Soils and Plants. CRC Press, Boca Ratón, Florida.

26. Kathiresan K, Bingham BL (2001) Biology of mangroves and mangrove ecosystems. Advances in Marine Biology 40: 81-251

27. Koch K, Ensikat H (2008) The hydrophobic coatings of plant surfaces: Epicuticular wax crystals and their morphologies, crystallinity and molecular self-assembly. Micron 39:759-772. https://doi.org/10.1016/j.micron.2007.11.010

28. Kvesitadze G, Khatisashvili G, Sadunishvili T, Kvesitadze E (2015) Plants for remediation: Uptake, translocation and transformation of organic pollutants. In: Öztürk M, Ashraf M, Aksoy A, Ahmad MS A, Hakeem KR (eds.) Plants, Pollutants and Remediation. Springer Netherlands, USA, pp. 241-305.

29. Lacerda LD, Rezende CE, José DV, Wasserman JC, Francisco MC (1985) Mineral concentration in leaves of mangrove trees. Biotropica 17:260-262.

30. Lacerda LD, Marins RV, Barcellos C, Molisani MM (2004) Sepetiba Bay: A Case Study of the Environmental Geochemistry of Heavy Metals in a Subtropical Coastal Lagoon. In: Drude de Lacerda 
L, Santelli RE, Duursma EK, Abrão JJ. (eds) Environmental Geochemistry in Tropical and Subtropical Environments. Environmental Science. Springer, Berlin, Heidelberg, pp. 293-318 https://doi.org/10.1007/978-3-662-07060-4_21

31. Larcher W (1996) Plant under stress in Physiological Plant Ecology: Ecophysiology and Stress Physiology of Functional Groups. Springer, Verlag

32. Liang J, Fang HL, Zhang TL, Wang XX, Liu YD (2017) Heavy metal in leaves of twelve plant species from seven different areas in Shanghai, China. Urban For Urban Green 27:390398. https://doi:10.1016/j.ufug.2017.03.006

33. Lichston JE, Godoy SAP (2006) Morphology and epicuticular wax content of coffee leaves after fungicide application. Pesq Agropec Bras 41:919-926. https://doi.org/10.1590/S0100204X2006000600004

34. Lima CS, Torres-Boeger MR, Carvalho LL, Pelozzo A, Sofiatti P (2013) Sclerophylly in mangrove tree species from South Brazil. Rev Mex Biodiv 84:1159-1166. https://doi.org/10.7550/rmb.32149

35. Lucena I, Maciel VEO, Silva JB, Galvincio, JD, Pimentel RMM (2011) Leaf structure of mangrove species to understand the spectral responses. RSE 2:19-31

36. Machado W, Silva-Filho EV, Oliveira RR, Lacerda LD (2002) Trace metal retention in mangrove ecosystems in Guanabara Bay, SE Brazil. Mar Pollut Bull 44:1277-1280. https://doi.org/10.1016/S0025-326X(02)00232-1

37. Marins RV, Lacerda LO, Villas Boas RC (1999) Relative importance of non-point sources of mercury to an industrialized coastal system, Sepetiba Bay, SE Brazil. In: Ebinghaus R, Turner RR, Lacerda LD, Vasiliev O, Salomons W (eds) Mercury contaminated sites. Springer-Verlag, Berlin, pp 207-220

38. Markert B (1992) Establishing of 'reference plant' for inorganic characterization of different plant species by chemical fingerprinting. Water, Air, Soil Pollut 64:533-538. https://doi.org/10.1007/BF00483363

39. Mathivanan K, Rajaram R (2013) Anthropogenic influences on toxic metals in water and sediment samples collected from industrially polluted Cuddalore coast, Southeast coast of India. Environ Earth Sci 72:997-1010. https://doi.org/10.1007/s12665-013-3017-4

40. Monte CN (2014) Análise da biodisponibilidade de metais a partir de ensaio de ressuspensão de sedimentos da Baía de Sepetiba, Rio de Janeiro. Dissertação apresentada ao Curso de Pósgraduação em Geociências da Universidade Federal Fluminense, Mestrado. Área de concentração: Geoquímica Ambiental (in Portuguese)

41. Naidoo G, Chirkoot D (2004) The effects of coal dust on photosynthetic performance of the mangrove, Avicennia marina in Richards Bay, South Africa. Environ Pollut 127:359-366. https://doi.org/10.1016/j.envpol.2003.08.018

42. Navarro E, Baun A, Behra R, Hartmann NB, Filser J, Miao A, Quigg A, Santschi PH, Sigg L (2008) Environmental behavior and ecotoxicity of engineered nanoparticles to algae, plants, and fungi. Ecotoxicol 17:372-386. https://doi.org/10.1007/s10646-008-0214-0 
43. Nyananyo BL, Bryai FO, Kiesekime SGG (2009) Laguncularia recemosa (L.) Gaertner f. (Family Combretaceae): gross morphology, phytochemistry, ecology and distribution in the Niger Delta. J Appl Sci Environ Manag 13:47-49.

44. Oku H, Baba S, Koga H, Takara K, Iwasaki H (2003) Lipid composition of mangrove and its relevance to salt tolerance. J Plant Res 116:37-45. https://doi.org/10.1007/s10265-002-0069-z

45. Prasad MNV, Hagemeyer J (1999) Heavy metal stress in plants - from molecules to ecosystems. Springer, Berlin, pp 1-27

46. Pérez-Sirvent C, Martínez-Sánchez MJ, Martínez-López S, Hernández-Córdoba M (2011) Antimony distribution in soils and plants near an abandoned mining site. Microchem J 97:52-56. https://doi.org/10.1016/j.microc.2010.05.009

47. Rafii ZA, Dodd RS, Fromard $F$ (1996) Biogeographic variation in foliar waxes of mangrove species. Biochem Syst Ecol 24:341-345. https://doi.org/10.1016/0305-1978(96)00029-4

48. Ribeiro AP, Figueiredo AMG, dos Santos JO, Dantas E, Cotrim MEB, Figueira RCL, Filho EVS, Wasserman JC (2013) Combined SEM/AVS and attenuation of concentration models for the assessment of bioavailability and mobility of metals in sediments of Sepetiba Bay (SE Brazil). Mar Pollut Bull 68:55-6. https://doi.org/10.1016/j.marpolbul.2012.12.023

49. Rocha AC, Canal EC, Campostrini E, Reis FO, Cuzzuol GRF (2009) Influence of chromium in Laguncularia racemosa (L). Gaertn f. physiology. Braz J Plant Physiol 21(2):87-94. https://doi.org/10.1590/S1677-04202009000200001

50. Rocha DS, Cunha BCA, Geraldes CM et al (2010) Metais pesados em sedimentos da Baía de Sepetiba, RJ: implicações sobre fontes e dinâmica da distribuição pelas correntes de maré. Geochim Bras 24:63-70.

51. Saenger P, McConchie D (2004) Heavy metals in mangroves: methodology, monitoring and management. Envis Forest Bulletin 4:52-62.

52. Severoglu Z, Ozyigit II, Dogan I, Kurmanbekova G, Demir G, Yalcin IE, Kari GK (2015) The usability of Juniperus virginiana L. as a biomonitor of heavy metal pollution in Bishkek City, Kyrgyzstan. Biotechnol Biotechnol Equip 29:1104-1112. https://doi.org/10.1080/13102818.2015.1072478

53. Seregin IV, Koszhevnikova A (2011) Histochemical methods for detection of heavy metals and strontium in the tissues of higher plants. Russ J Plant Physiol 58:721-727. https://doi.org/10.1134/S1021443711040133

54. Seregin I, Koszhevnikova A, Schat H (2015) Histochemical detection of Zn in plant tissues. Bioprotocol 5:1-6.

55. Shahid M, Khalid S, Dumat C, Pierart A, Niazi NK (2019) Biogeochemistry of antimony in soil-plant system: ecotoxicology and human health. Appl Geochem 106: 45-59. https://doi.org/10.1016/j.apgeochem.2019.04.006

56. Silva BO, Victório CP, Arruda RCO (2020) Anatomical and Micromorphological Traits in Leaf Blade of Halophytes from a Brazilian Sandy Coastal Plain. Handbook of Halophytes 1-30. https://doi.org/10.1007/978-3-030-17854-3_30-1 
57. Silva JM, Martin MBG, Cavalheiro AJ (2010) Caracterização anatômica e perfis químicos de folhas de Avicennia schaueriana Stapf. \& Leech. ex Moldenke e Rhizophora mangle L. de manguezais impactados e não impactados do litoral paulista. Insula 39:14-33.

58. Silva CA, Madureira LA (2012) Source correlation of biomarkers in a mangrove ecosystem on Santa Catarina Island in southern Brazil. An Acad Bras Ciênc 84:589-604. https://doi.org/10.1590/S000137652012005000042

59. Silva FS (2017) Avaliação da qualidade da água da Baía de Sepetiba próximo aos canais DomPedro Guandu, São Francisco e Itá. Dissertation, Universidade Estadual da Zona Oeste - UEZO (in Portuguese)

60. Silva LTDM; Victório CP (2021) Áreas verdes na Zona Oeste do Rio de Janeiro: patrimônio ambiental de Mata Atlântical Green areas in the West Zone of Rio de Janeiro: the environmental heritage of Atlantic Forest. Meio Ambiente (Brasil) 3:112-136.

61. Sleimi N, Kouki R, Ammar MH, Ferreira R, Pérez-Clemente R (2021) Barium effect on germination, plant growth, and antioxidant enzymes in Cucumis sativus L. plants. Food Sci Nutr 9:2086-2094. https://doi.org/10.1002/fsn3.2177

62. Sobrado MA (2004) Influence of external salinity on the osmolality of xylem sap, leaf tissue and leaf gland secretion of the mangrove Laguncularia racemosa (L.) Gaertn. Trees 18:422427. https://doi:10.1007/s00468-004-0320-4

63. Sugiyama M (1995) A flora do manguezal. In: Schaeffer-Novelli Y (coord.) Manguezal ecossistema entre a terra e o mar. Caribbean Ecol Res, São Paulo, pp 17-20

64. Tafolla-Arellano JC, Báez-Sañudo R, Tiznado-Hernández ME. 2018. The cuticle as a key factor in the quality of horticultural crops. Sci Horticult 232:145-152. https://doi.org/10.1016/j.scienta.2018.01.005

65. Tomlinson PB (1986) The Botany of Mangroves. Cambridge University Press, Cambridge, U.K.

66. Tonhá MS, Garnier J, Araújo DF, Cunha BCA, Machado W, Dantas E, Araújo R, Kutterf VT, Bonnet M-P, Seyler $P$ (2020) Behavior of metallurgical zinc contamination in coastal environments: A survey of $\mathrm{Zn}$ from electroplating wastes and partitioning in sediments. Sci Total Environ 743, 140610. https://doi.org/10.1016/j.scitotenv.2020.140610

67. Victório CP, dos Santos MS, de Mello MC, Bento JPSP, Souza MC, Simas NK, Arruda RCO (2020) The presence of heavy metals in Avicennia schaueriana Stapf \& Leechman ex Moldenke leaf and epicuticular wax from different mangroves around Sepetiba Bay, Rio de Janeiro, Brazil. Environ Sci Pollut Res 27: 23714-23729. https://doi.org/10.1007/s11356-020-08606-6

68. Victório CP, dos Santos MS, Simas NK (2021) Phthalates: environmental pollutants detected in leaf epicuticular wax of Avicennia schaueriana and Rhizophora mangle from a mangrove ecosystem, Int J Environ Studies, 1-10. https://doi.org/10.1080/00207233.2021.1875298

69. Viégas RN (2006) Desigualdade ambiental e "zonas de sacrifício". Mapa dos conflitos ambientais no estado do Rio de Janeiro. Rio de Janeiro, FASE/IPPUR 1:1-21 
70. Wasserman JC, Figueiredo AMG, Pellegatti F, Silva-Filho EV (2001) Elemental composition of sediment cores from a mangrove environment using neutron activation analysis. J Geochem Exploration 72:129-146. https://doi.org/10.1016/S0375-6742(01)00158-3

71. Wasserman JC (2005) O impacto da mobilização química de metais durante um serviço de dragagem na Baía de Sepetiba para o terminal marítimo da CSA. Mobilidade de Metais em Sepetiba. Relatório de dragagem para a Companhia Siderúrgica do Atlântico (in Portuguese)

72. Wasserman JC, Barros SR, Lima GBA (2013) Planning dredging services in contaminated sediments for balanced environmental and investment costs. J Environ Manag 121:48-56. https://doi.org/10.1016/j.jenvman.2013.02.024

73. Wuytack T, Wuyts K, Van Dongen S et al (2011) The effect of air pollution and other environmental stressors on leaf fluctuating asymmetry and specific leaf area of Salix alba L. Environ Pollut 159:2405- 2411

74. Zayed A, Terry N (2003) Chromium in the environment: factors affecting biological remediation. Plant Soil 249:139-56. https://doi.org/10.1023/A:1022504826342

75. Zhang C, Feng Y, Liu Y-W, Chang H-q, Li Z-j, Xue J-m (2017) Uptake and translocation of organic pollutants in plants: A review. J Integr Agricult 16:1659-1668. https://doi.org/10.1016/S20953119(16)61590-3

\section{Figures}




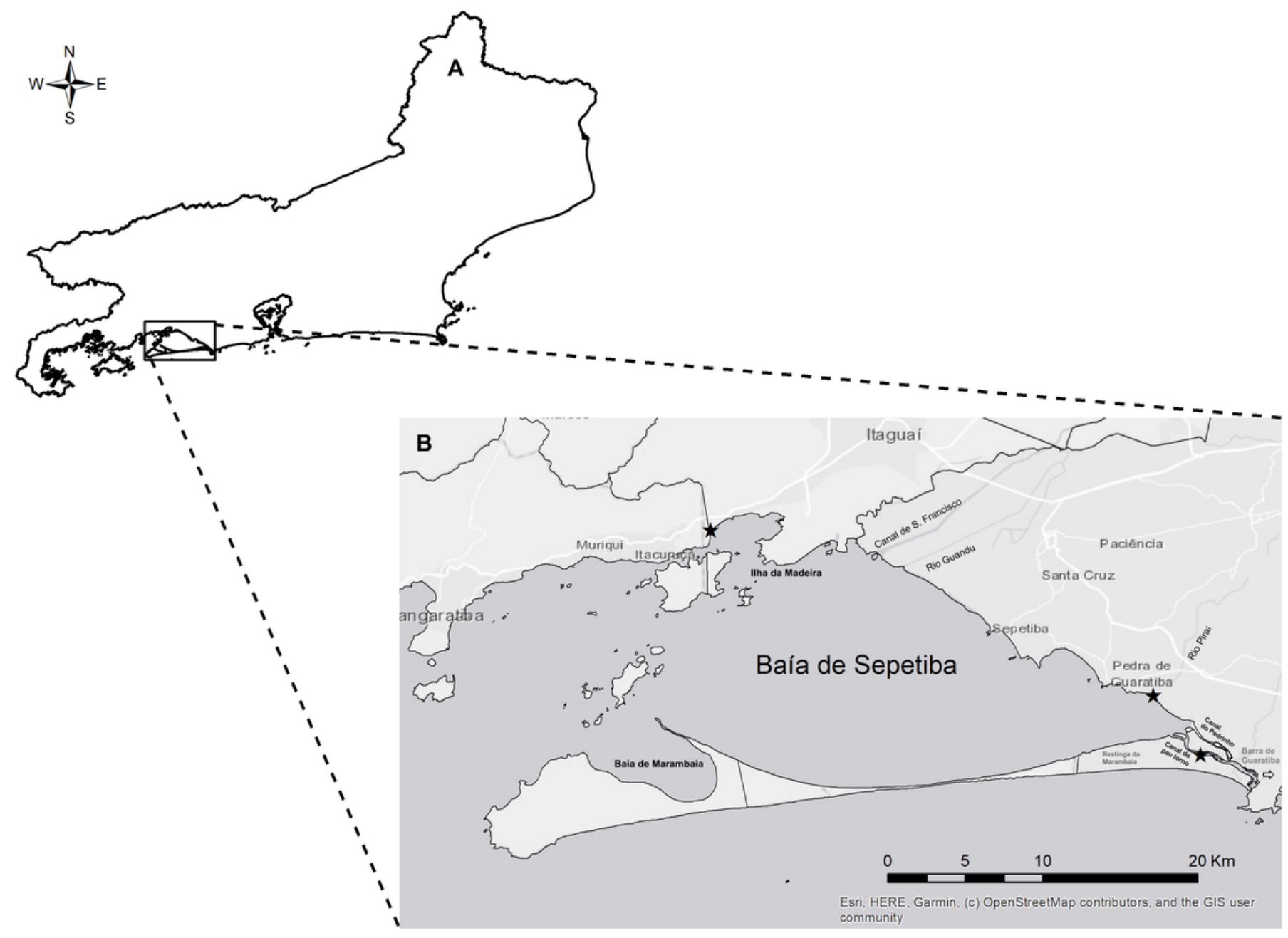

\section{Figure 1}

A. Rio de Janeiro City. B. Location of mangroves around Sepetiba Bay (Baía de Sepetiba, Rio de Janeiro) where Laguncularia racemosa leaves were collected $\left({ }^{*}\right)$. The black stars indicate mangroves: Coroa Grande (Itaguaí City), Pedra de Guaratiba (Rio de Janeiro City) and Marambaia (Rio de Janeiro City). In Itaguaí and Santa Cruz, there are industrial centers.
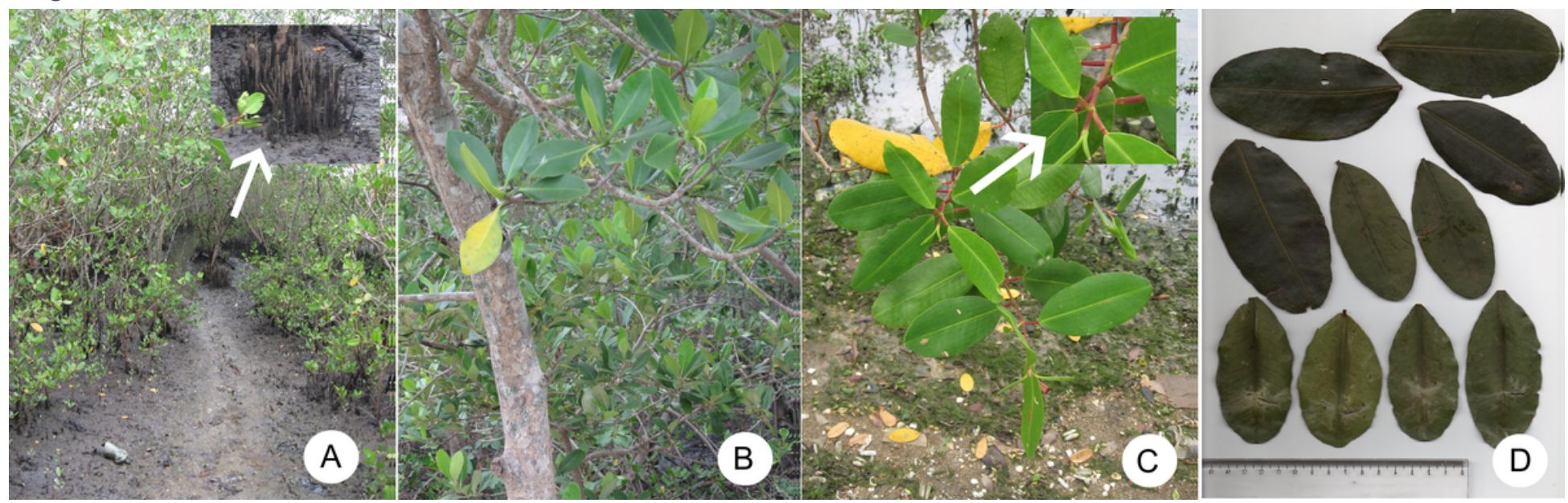

Figure 2 
Plant habit, collection sites and leaves of Laguncularia racemosa in Rio de Janeiro State, Brazil, around Sepetiba Bay. A-C. Tree with pneumatophores (in detail) from Coroa Grande Mangrove. C. Red petiole of leaves (in detail). D. Morphological variation in leaves of L. racemosa in mangrove and organized to scan for analysis of leaf area (D).

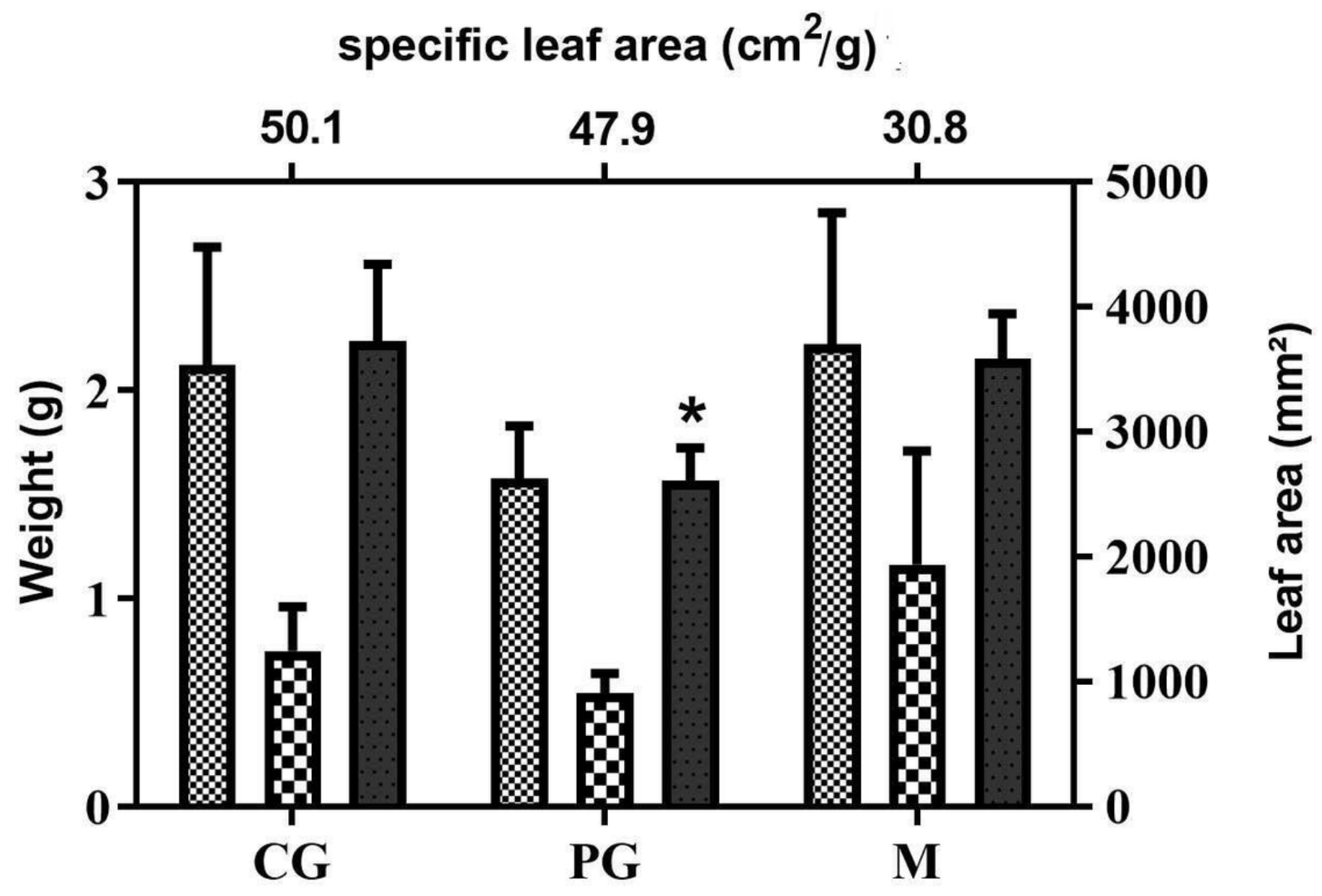

$\infty$ fresh weight $\quad \mathbf{m}$ dry weight $\quad \cdots$ leaf area

Figure 3

Fresh and dry weight (g), leaf area (mm2) and specific leaf area (SLA) of Laguncularia racemosa collected in mangroves of Marambaia (M), Coroa Grande (CG) and Pedra de Guaratiba PG), around Sepetiba Bay. *Significant difference, $p<0.0002$. 

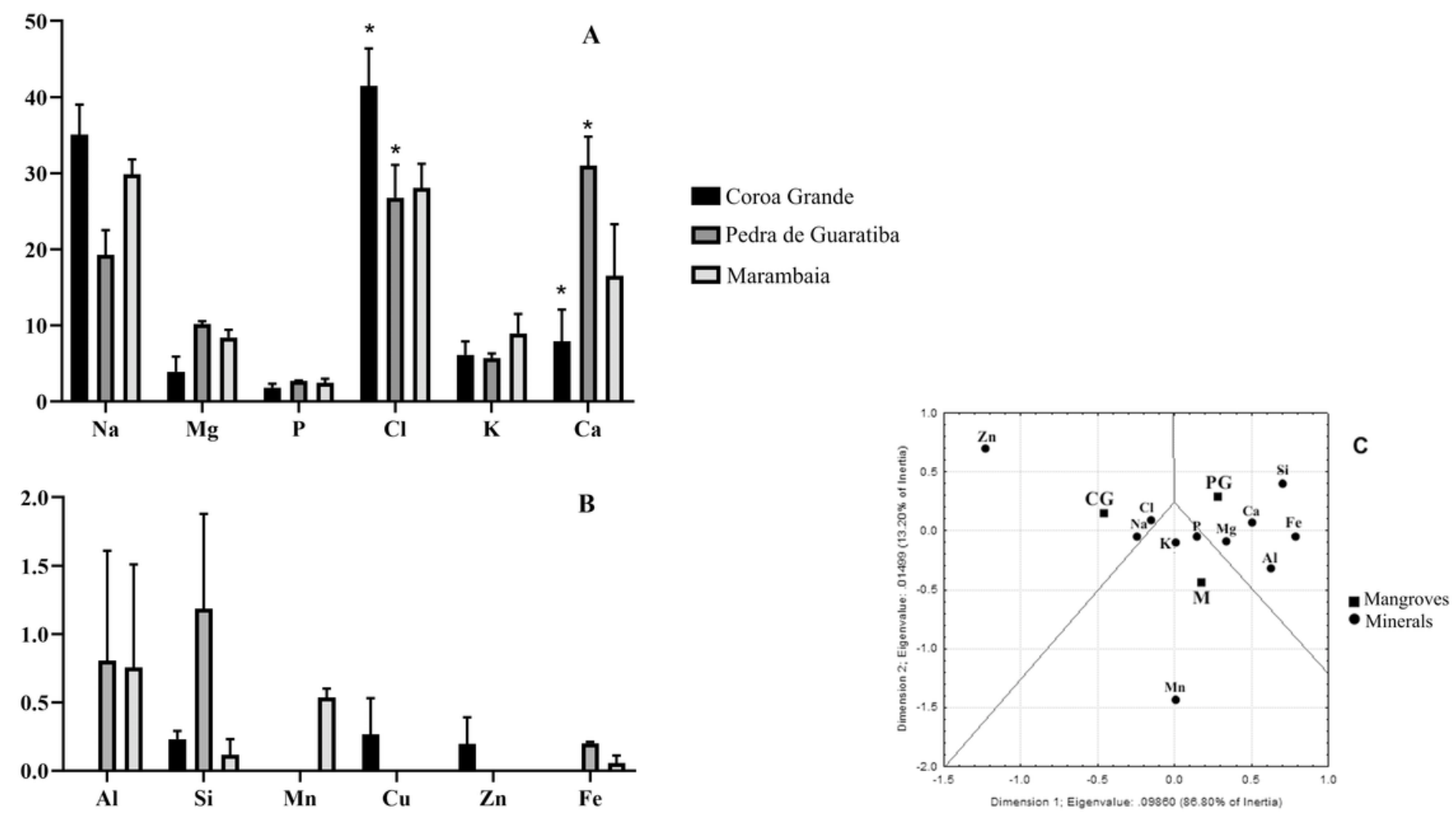

\section{Figure 4}

Relative quantity in number of atoms per mineral (chemical element) expressed in ATOM (\%) of leaf of Laguncularia racemosa by analysis of ashes of leaves using Energy Dispersive X-Ray Spectroscopy (EDS). Al: aluminum; Si: Silicon, Fe: iron; Mn: manganese; Cu: copper, Zn: zinc; Ca: calcium; K: potassium; Mg: magnesium; Na: sodium, Cl: chlorine; P: phosphorous. Mangroves around Sepetiba Bay, Rio de Janeiro (Brazil): Coroa Grande (CG), Marambaia (M) and Pedra de Guaratiba (PG). A. Essential minerals; B. Heavy metals. *Significant difference $\mathrm{Cl}(C G$ and $P G, p<0.01)$ and $\mathrm{Ca}(C G$ and $P G, p<0.0001)$. C. Correspondence analysis of the number of atoms per mineral (chemical element) expressed in ATOM (\%) of $\mathrm{L}$. racemosa leaves collected in the mangroves. 

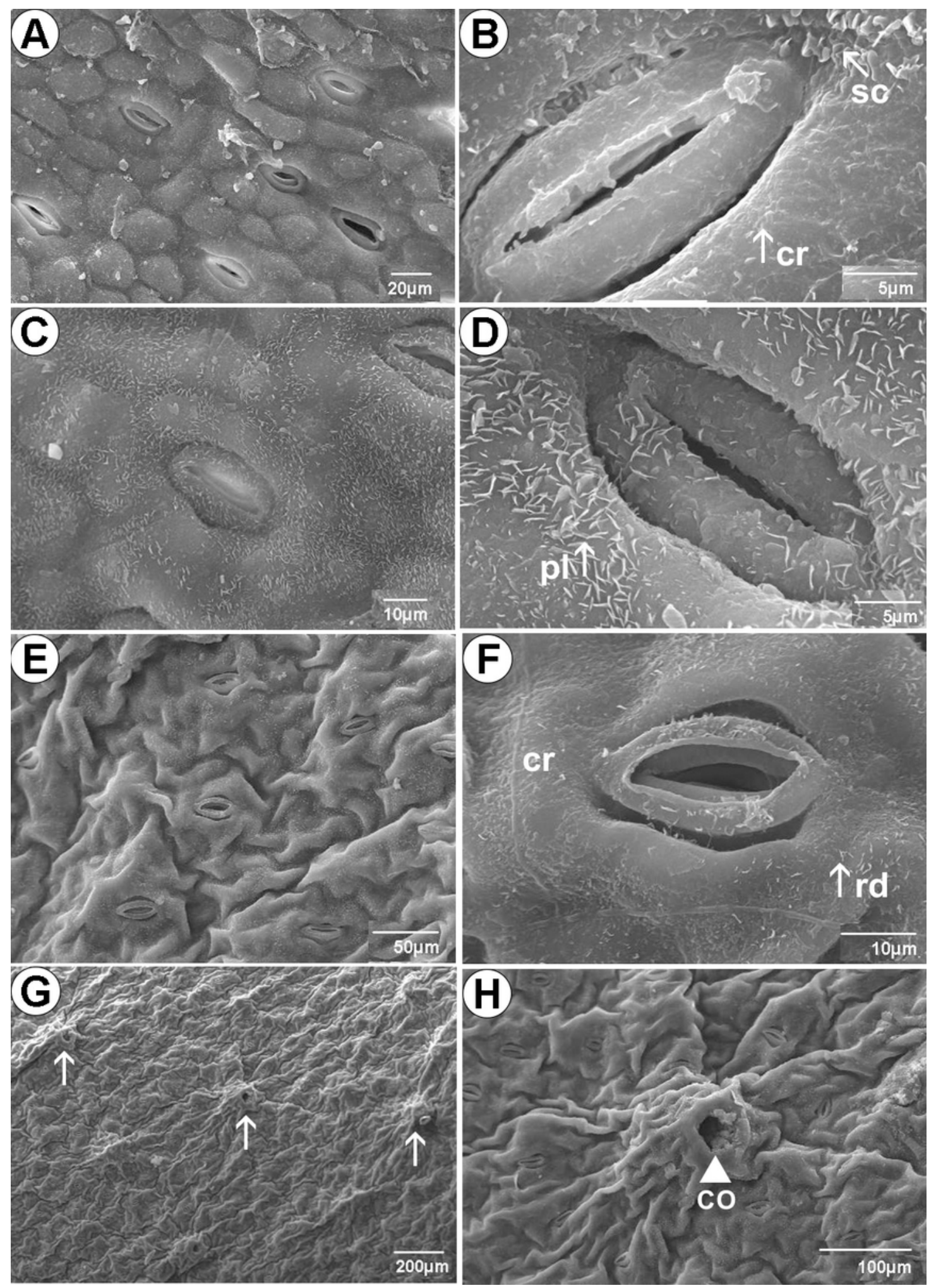

\section{Figure 5}

Leaf micromorphology of Laguncularia racemosa from three mangrove areas in Rio de Janeiro State (Brazil), showing different epicuticular wax deposition, stomata and pore of salt secretory structure located in a cavity by electronic microscopy. A-B. Marambaia (M) mangrove: epicuticular wax layer in crusts (cr) and scales near a stoma; C-D. Pedra de Guaratiba (PG) mangrove: epicuticular wax in plates (pl) in all surface, including next stoma. E-H. Coroa Grande (CG) mangrove: epicuticular wax in crusts, 
some rodlets (rd) over ordinary epidermal cells and stoma. G-H: abaxial epidermis of L. racemosa from CG mangrove showing opening of epidermal cavity (co) where secretory multicellular glandular trichomes are located. A, C-H. Abaxial surface. B. Adaxial surface.
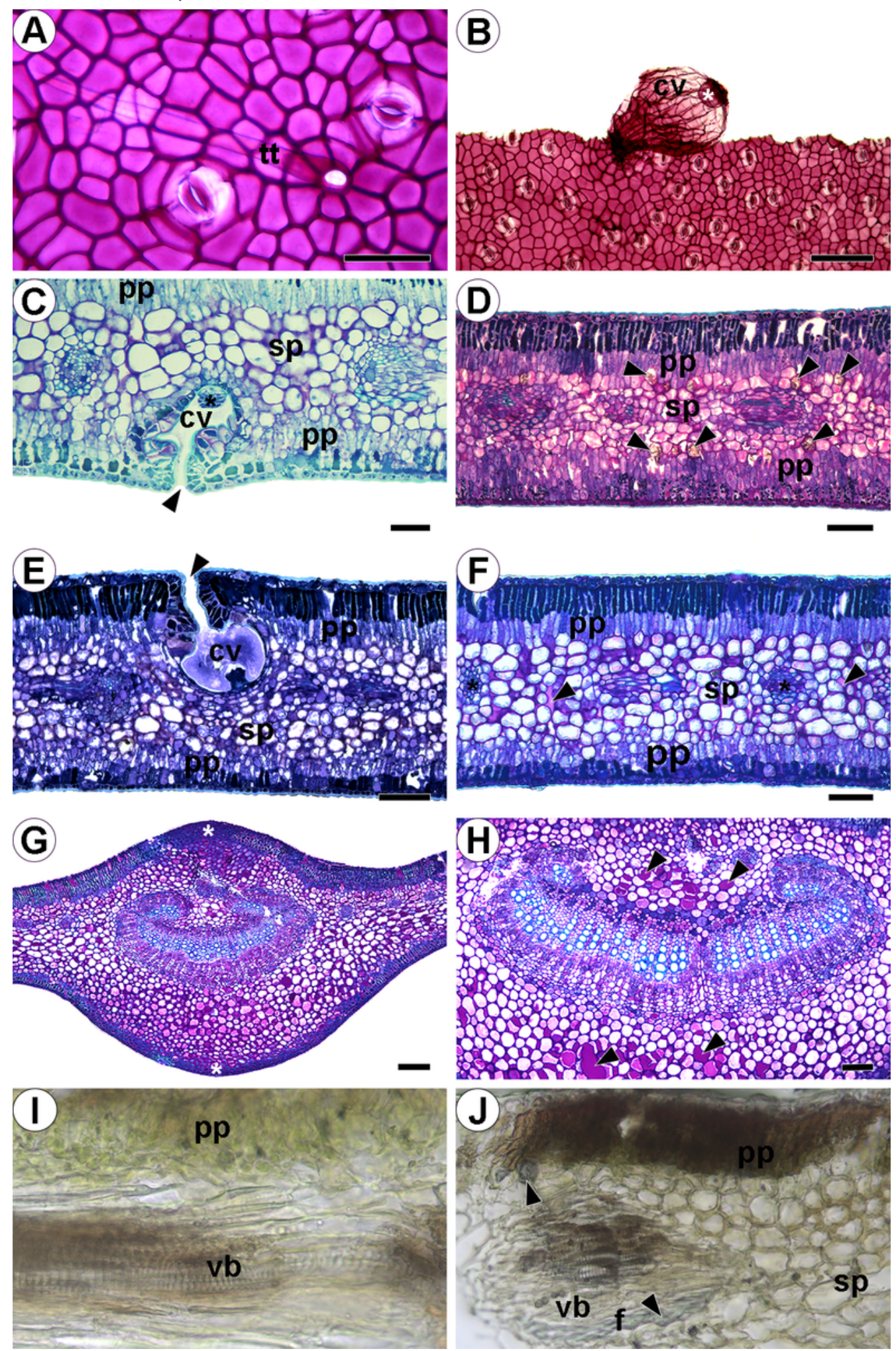

Figure 6

Anatomical analysis of Laguncularia racemosa leaves collected in different mangroves in Rio de Janeiro (Brazil), under light microscopy. A-B. epidermises in frontal view showing ordinary epidermal cells, 
stomata, unicellular non-glandular trichome (tt), and secretory cavity (cv) after removal of the mesophyll with a salt secretory trichome at the bottom $(*)$; C. Leaf cross section showing cavity (cv) on the abaxial epidermal surface where the salt secretory trichome $(*)$ is located, with opening to external environment (black arrowhead), palisade parenchyma (pp) and spongy parenchyma (sp). D. Leaf from Coroa Grande (CG): palisade parenchyma (pp) and spongy parenchyma (sp), crystal idioblasts with druses (black arrowheads). E. Leaf from Pedra de Guaratiba (PG): adaxial secretory cavity (cv) with pore (black arrowheads). F. Leaf from Marambaia (M): palisade parenchyma (pp), spongy parenchyma, collateral vascular bundles $\left({ }^{\star}\right)$, black arrowheads point to mucilage from spongy parenchyma cells. G. Midvein cross section showing cortical and medullary parenchyma storing phenolic compounds $\left({ }^{\star}\right)$. H. Main vascular bundle evidencing phenolic idioblasts and mucilage (black arrowheads). I. Cross section of leaf with Zincon® reagent; plant from Marambaia. J. Cross section with leaf with Zincon ${ }^{\circledR}$ reagent, evidencing zinc in fibers and idioblasts with druse crystals; plant from CG. A, E. Coroa Grande mangrove; B, F, H. Marambaia mangrove and D, G. Pedra de Guaratiba mangrove.
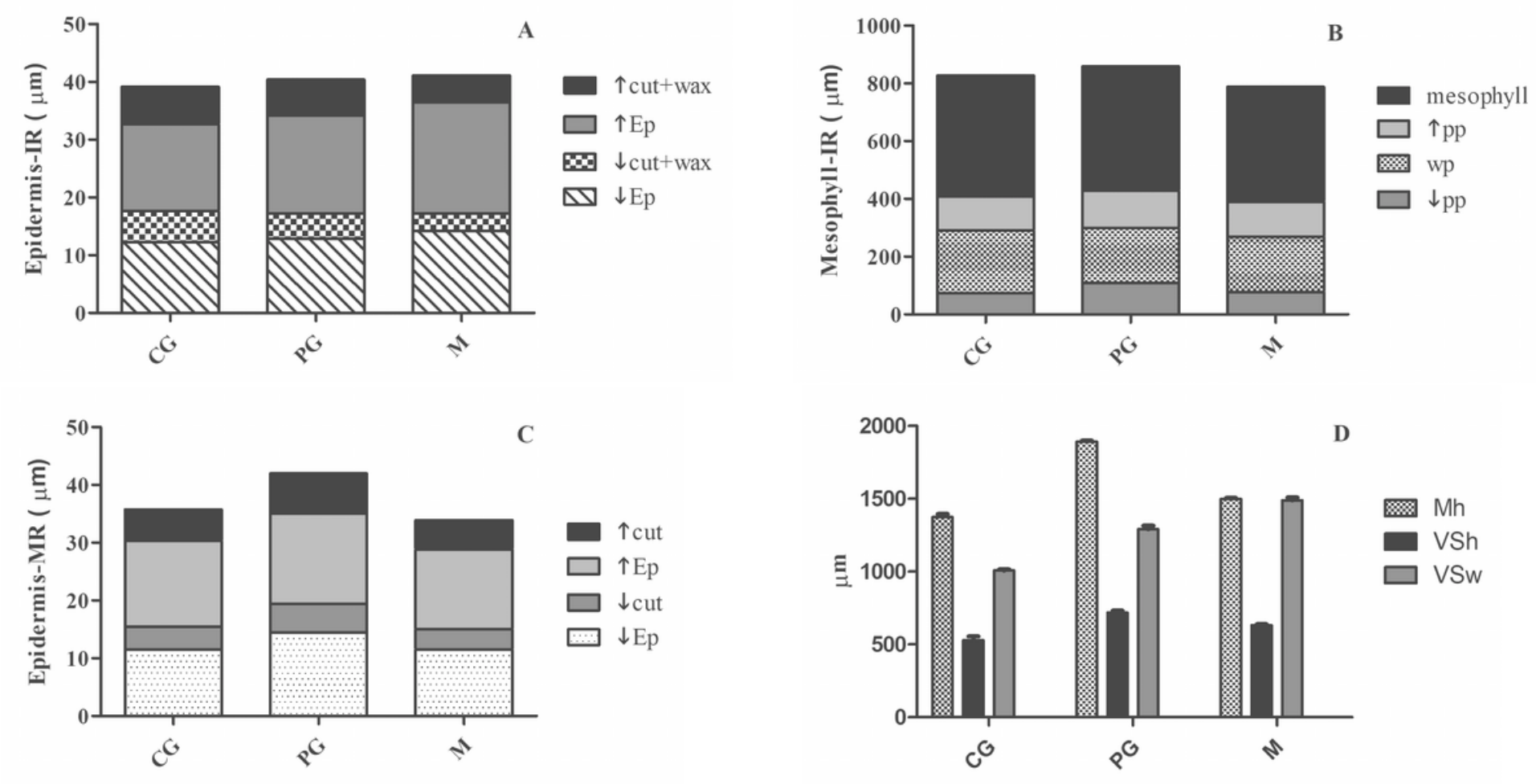

\section{Figure 7}

Leaf anatomical parameters from intercostal region (epidermis and mesophyll) and midvein (epidermis and vascular system) from leaf samples of Laguncularia racemosa collected in the Coroa Grande (CG), Pedra de Guaratiba (PG) and Marambaia (M) mangroves of Rio de Janeiro (Brazil). No significant differences were verified (Tukey`s test, $p<0.05)$. A. wax (w) + cuticle (cut) + epidermis (ep) intercostal region (IR). B. mesophyll IR: palisade parenchyma - pp, water parenchyma -wp. C. cuticle + epidermis midvein region (MR). $\uparrow$ - adaxial $\downarrow$ - abaxial, D. Mh - Midvein height, VSh - Vascular system height, VSw Vascular system width. 